\title{
Temporal Fluctuations in Weather and Climate Extremes That Cause Economic and Human Health Impacts: A Review

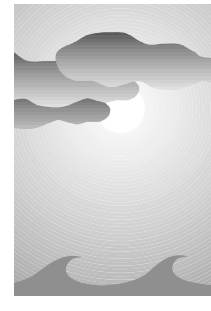

\author{
Kenneth E. Kunkel, ${ }^{*}$ Roger A. Pielke Jr., ${ }^{+}$and Stanley A. Changnon*
}

\begin{abstract}
This paper reviews recent work on trends during this century in societal impacts (direct economic losses and fatalities) in the United States from extreme weather conditions and compares those with trends of associated atmospheric phenomena. Most measures of the economic impacts of weather and climate extremes over the past several decades reveal increasing losses. But trends in most related weather and climate extremes do not show comparable increases with time. This suggests that increasing losses are primarily due to increasing vulnerability arising from a variety of societal changes, including a growing population in higher risk coastal areas and large cities, more property subject to damage, and lifestyle and demographic changes subjecting lives and property to greater exposure.

Flood damages and fatalities have generally increased in the last 25 years. While some have speculated that this may be due in part to a corresponding increase in the frequency of heavy rain events, the climate contribution to the observed impacts trends remains to be quantified. There has been a steady increase in hurricane losses. However, when changes in population, inflation, and wealth are considered, there is instead a downward trend. This is consistent with observations of trends in hurricane frequency and intensity. Increasing property losses due to thunderstorm-related phenomena (winds, hail, tornadoes) are explained entirely by changes in societal factors, consistent with the observed trends in the thunderstorm phenomena. Winter storm damages have increased in the last 10-15 years and this appears to be partially due to increases in the frequency of intense nor'easters. There is no evidence of changes in drought-related losses (although data are poor) and no apparent trend in climatic drought frequency. There is also no evidence of changes in the frequency of intense heat or cold waves.
\end{abstract}

\section{Introduction}

In recent years, extreme weather events have led to ever larger economic losses in the United States. Multibillion dollar losses now occur with increasing frequency. The trend in losses has led many to conclude that the United States has witnessed changes in the frequency and/or intensity of extreme events. These perceptions are more than idle speculationsthey underlie policy decisions with important social,

\footnotetext{
*Urbana, Illinois.

+National Center for Atmospheric Research, Boulder, Colorado. \#Changnon Climatologists, Mahomet, Illinois.

Corresponding author address: Kenneth E. Kunkel, 1301 E. Eliot, Urbana, IL 61801.

E-mail: k-kunkel@uiuc.edu

In final form 1 October 1998.

(C1999 American Meteorological Society
}

economic, and political ramifications, such as those related to climate change and natural disasters. This paper has two objectives. First, it seeks to provide a review of recent work on trends in economic losses associated with extreme events in the United States. This paper focuses on phenomena identified at a 1997 U.S. Weather Research Program workshop as being the most significant from the standpoint of societal impacts. ${ }^{1}$ These phenomena are floods, hurricanes, winter storms, extreme heat and cold, thunderstormrelated events (hail, tornadoes, lightning), and droughts.

${ }^{1}$ This is not to diminish the impacts associated with other atmospheric phenomena (such as fog) and more routinely disruptive events. Rather the focus is on those events typically identified as "extreme." Note that in this paper droughts have been added to those events considered at the 1997 workshop. 
The second objective of this paper is to build upon past work that seeks to establish a link between the measures of extremes used by atmospheric scientists and information that is usable by decision makers. The most prominent of these efforts is the development of a "climate extremes index" by Karl et al. (1996) intended as a summary of "multivariate, multidimensional changes such that they can be readily understood and used in policy decisions made by nonspecialists" (p. 289). The climate extremes index developed by Karl et al. is based on five indicators of extremes.

1) The sum of (i) percentage of the United States with maximum temperatures much below normal and (ii) percentage of the United States with maximum temperatures much above normal.

2) The sum of (i) percentage of the United States with minimum temperatures much below normal and (ii) percentage of the United States with minimum temperatures much above normal.

3) The sum of (i) percentage of the United States in severe drought (equivalent to the lowest tenth percentile) based on the Palmer Drought Severity Index (PDSI) and (ii) the percentage of the United States with severe moisture surplus (equivalent to the highest tenth percentile) based on the PDSI.

4) Twice the value of the percentage of the United States with a much greater than normal number of days with precipitation derived from extreme (more than $50.8 \mathrm{~mm}$ ) 1-day precipitation events.

5) The sum of (i) percentage of the United States with a much greater than normal number of days with precipitation and (ii) percentage of the United States with a much greater than normal number of days without precipitation.

We seek to build on the efforts of Karl et al. by identifying from existing work those climatic measures that appear to most directly indicate a covarying societal impact. For instance, to select a straightforward example, the societal impacts of hurricanes are closely correlated with the frequency of landfalling, SaffirSimpson category 3-4-5 storms, which account for more than $80 \%$ of economic losses (Pielke and Landsea 1998). Thus, the frequency of category 3-45 storms is a candidate for inclusion in an extremes index. Unfortunately, for societal impacts associated with other phenomena, there is not as clear a linkage between what is measured by atmospheric scientists and related societal impacts.
A fundamental assumption underlying this paper is that for an index of climate extremes to be most useful to decision makers, it should be based on those measures that covary with impacts. Because society changes as climate fluctuates, any analysis of past trends that seeks to identify a climate signal in the impacts record must take care to control for societal changes in some manner. As a precursor to further research in this area, this paper explores those climatic measures that might covary with trends in economic losses and thus be candidates for inclusion in climate extremes indices of use to policymakers.

\section{Data and methodological issues}

\section{a. Societal impacts}

The quantitative assessment of the impacts on society of weather and climate extremes is challenging. There is no centralized collection of data and no standardized methodology. Thus, any assessment must pay attention to at least three factors: 1) how impacts are measured, 2) what is overlooked through reliance on available quantitative information, and 3) the interrelation of atmospheric and societal trends that underlie overall trends in impacts.

First, the analyst's choice of the temporal and spatial scale of the impacts affects the assessment. Over different periods and areas one can arrive at different, but equally valid, measures of impacts. For instance, while a local community might experience devastating losses immediately following a weather disaster, at a regional or national scale there are those who might benefit over a longer period through such effects as increased commodity prices or an increased demand for building supplies. In general this paper focuses on direct impacts (i.e., economic or loss of life) that are immediately related to the event and are generally the most easily measured. ${ }^{2}$ Second-order impacts (e.g., costs associated with providing fresh water and supplies) may be incurred days or weeks after the event. Third- or higher-order impacts (e.g., loss of tourist revenue, change in tax revenues) may occur months or years later and are difficult to identify and quantify amid the normal variability of social processes.

${ }^{2}$ Even attribution of loss of life to atmospheric extremes is fraught with methodological difficulties. See, for example, Parrish (1997) and Donoghue et al. (1997). 
A second factor is the difficulty in quantifying certain losses, such as human hardship. Measurable economic losses and casualties are not all that matters. This paper explicitly recognizes that those indicators that are most readily available do not necessarily represent the total impacts of weather and climate on society. This paper focuses on economics and loss of life as important subsets of the broader impacts to society related to atmospheric phenomena.

Third, to accurately interpret trends in economic losses or lives lost from past weather events, an understanding of the causes of those trends is required. Because societal impacts are a joint function of atmospheric events and human action, the analyst must take care to discern which combination of factors drive overall trends in impacts. To control for societal change, economic losses must be adjusted for inflation and other relevant changes such as population growth and increasing wealth. Loss of human life is also influenced by population density, standards and styles of living, and improvements in forecasting and warning systems for severe weather events. Normalization methodologies have been employed in a number of contexts (but not all) to help identify a climate signal in the impacts record.

\section{b. Weather and climate extremes}

There are at least four important challenges in assessing trends in measures of extremes that are closely related to impacts. First, there may be limitations in the length and homogeneity of the climate data record. For certain extremes, particularly temperature and precipitation, there exist lengthy and rather homogeneous records that allow assessment of long-term trends. For other extremes, such as those related to tornadoes, the records are not as lengthy and not homogeneous over time.

Second, there may be limitations in the spatial and temporal resolution of the data record. The existing meteorological observing network is not dense enough to capture all significant events. For example, hail, wind, and flash flood damage caused by thunderstorms is often highly localized.

Third, it is desirable to have national measures of extremes. However, the physical cause of impacts may vary regionally. For example, snowmelt is a major cause of damaging floods in northern regions. "Heavy" rainfall causes floods in all regions, but heavy is a relative term. As another example, the size of the drainage basin affects the linkage to precipitation. Damaging flooding on the main stem of a large river basin, such as the Mississippi, requires heavy precipitation over a large area and a lengthy period. By contrast, damaging flooding on a small tributary might be triggered by highly localized, short-duration, high-intensity rainfall.

Fourth, the physical linkages between extremes and societal impacts are often complex and dependent on several factors. For example, crop damage can be critically dependent on the timing of an extreme. Extreme heat will have a greater adverse effect on corn yield if it occurs during the 2-4-week window of pollination than at any other crop stage. This window will vary from year to year, depending on time of planting and rate of crop development, complicating the construction of a simple long-term index of crop stress. Also, the quantitative effects of extremes on crop yields and on other physical and human systems is not completely understood in many cases.

These factors serve to decrease the correlation between time series of extremes and impacts. To the extent possible, we have used measures of extremes shown by past studies to be correlated with impacts and have also identified where a correlation has not been shown.

\section{Aggregate national trends in the impacts of climate and weather extremes}

Table 1 summarizes data presented at a recent workshop (Pielke 1997a) on the direct impacts of recent extreme events in the United States as measured by loss of life and economic losses. An estimate of national losses experienced in the early 1990s is on the order of $\$ 300$ million per week (current dollars). Of course, damages from natural disasters do not occur in a systematic fashion. There are long periods of no significant impacts and then brief periods of large impacts. We present the loss information in terms of dollars per week for two reasons. 1) It provides decision makers (including the public) with a sense of the losses society experiences in a readily comprehensible manner, and 2) the White House Office of Science and Technology Policy currently uses such units in ongoing policy debate. The number is conservative because it neglects the effects of inflation, extreme temperatures, and drought. It is reasonable to conclude that the addition of the other phenomena and adjustment for inflation could increase the number by a factor of 2 or more. Caution is urged in the use of this aggregate fig- 
TABle 1. Summary of data on recent extreme event impacts in the United States. Further documentation available at www.dir.ucar.edu/esig/socasp/weather1

\begin{tabular}{|c|c|c|c|c|}
\hline Event & $\begin{array}{l}\text { Annual mean } \\
\text { loss of life } \\
\text { (period) }\end{array}$ & $\begin{array}{l}\text { Annual mean } \\
\text { current } \$ \text { loss } \\
\quad(\text { period })\end{array}$ & $\begin{array}{l}\text { Recent extreme } \\
\text { event, } \$ \text { loss, } \\
\text { deaths, (date) }\end{array}$ & Sources \\
\hline Floods & 96 (1986-95) & $\$ 2.4 \mathrm{~B}(1984-93)$ & $\begin{array}{c}\$ 20 \mathrm{~B}(1993) \\
156(1976)\end{array}$ & $\begin{array}{l}\text { Pielke (1996), } \\
\text { Yen and Yen (1996), } \\
\text { Meyers (1997) }\end{array}$ \\
\hline Hurricanes & 20 (1986-95) & \$6.2B (1989-95) & $\begin{array}{l}\$ 30 \mathrm{~B}(1992) \\
256(1969)\end{array}$ & $\begin{array}{l}\text { Pielke (1997b), } \\
\text { Hebert et al. (1996) }\end{array}$ \\
\hline Winter storms & 47 (1988-95) & $>\$ 1 \mathrm{~B}($ est $)$ & $\begin{array}{c}\$ 6 B(1993) \\
200+(1993)\end{array}$ & $\begin{array}{l}\text { Parish (1997), } \\
\text { Kocin (1997) }\end{array}$ \\
\hline Tornadoes & 44 (1985-95) & \$2.9B (1991-94) & $\begin{array}{l}\text { \$3.8B (1993) } \\
94(1985)\end{array}$ & $\begin{array}{l}\text { Roth (1996), } \\
\text { Golden (1997) }\end{array}$ \\
\hline Extreme heat & 384 (1979-92) & $?$ & $\begin{array}{c}>\$ 15 \mathrm{~B}(1980) \\
522(1995)\end{array}$ & $\begin{array}{l}\text { Parish (1997), } \\
\text { Adams (1997) }\end{array}$ \\
\hline Extreme cold & 770 (1968-85) & $?$ & $>\$ 30 \mathrm{~B}(1976-77)$ & $\begin{array}{l}\text { Kilbourne (1997), } \\
\text { Adams (1997) }\end{array}$ \\
\hline Lightning & $175(1940-81)$ & $>\$ 1 \mathrm{~B}($ est $)$ & $?$ & Kithil (1997) \\
\hline Hail & - & $\$ 2.3 \mathrm{~B}$ (est) & $\$ 650 \mathrm{M}(1990)$ & Changnon (1997) \\
\hline Annual averages & $>1500$ & $>15.8 \mathrm{~B}$ & & \\
\hline
\end{tabular}

ure: it is an approximation that illustrates the relative magnitude of weather and climate impacts on the United States. Different measures might arrive at smaller or larger results. Annual loss of life is estimated to be on the order of 1500 (see Table 1). Caution is advised here as well, as this number neglects the 6000 or so people who lose their lives in weather-related traffic fatalities. While lightning has perennially been associated with a large loss of life, the largest loss of life in recent years has been associated with extreme temperatures. ${ }^{3}$

Insurance data (Fig. 1) also provide a measure of national economic losses. The nonnormalized (Fig. 1a) data show a trend of increasing losses. Prior to the late 1970s annual losses were on the order of a few hundred million dollars (U.S. Congress 1995). During the $1980 \mathrm{~s}$, losses had increased to the $\$ 0.5-\$ 2.5$ billion

${ }^{3}$ Considerable documentation on these numbers is available in Pielke (1997a). range. Then, in 1989, losses increased dramatically. Annual insured losses from 1989-97 were as follows: $\$ 7.4, \$ 2.5, \$ 3.0, \$ 21.9, \$ 4.4, \$ 4.5, \$ 8.2, \$ 7.4$, and $\$ 3.1$ billion (U.S. Congress 1995). There has been a clear change in impacts on the insurance industry.

The property insurance industry has identified each weather event causing insured losses of $\$ 5$ million or more since 1949, and these are labeled as "catastrophes." Insurance experts have normalized the past catastrophe values based on inflation, changes in insurance coverages, and shifts in density of structures to derive an adjusted catastrophe database normalized to 1994 values. This allows comparison of catastrophes between years and over time during the 194994 period (Changnon and Changnon 1998). Both the number of events and amount of losses show steady increases over time (Changnon et al. 1997). Figure 1b presents the losses, based on 896 catastrophes causing $\$ 10$ million or more in losses between 1949 and 1994, divided by the nation's population. The resulting values reveal no trend. Five years have peaks 
a)

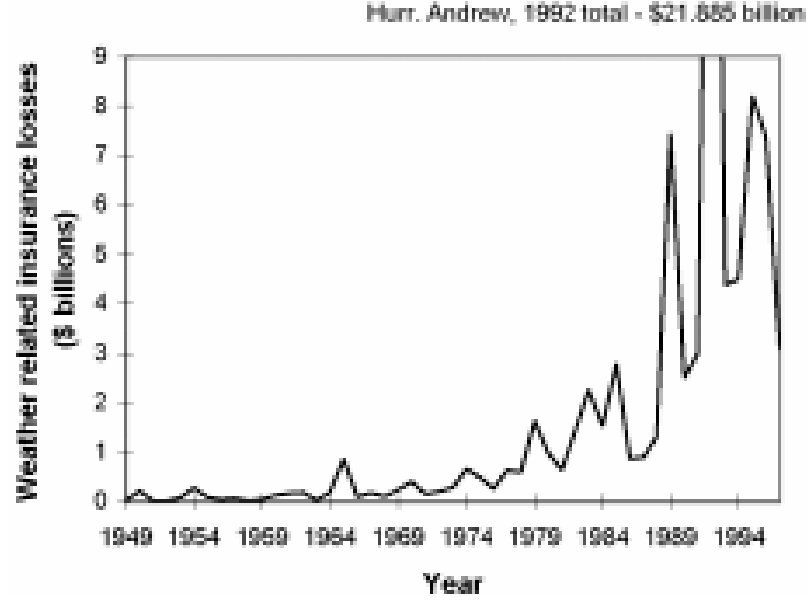

b)

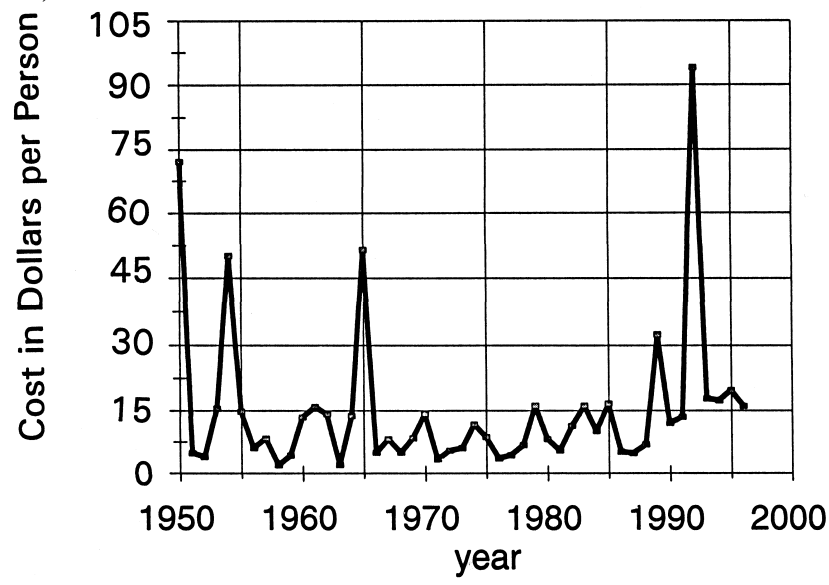

FIG. 1. Weather-related insurance statistics: (a) annual weather-related losses to the insurance industry for 1950-96; (b) number of insurance-defined catastrophes and the dollar losses for 1950-94 for catastrophes causing losses between $\$ 10$ and $\$ 100$ million, compared to the U.S. population (from Changnon et al. 1997).

$(1949,1954,1965,1989$, and 1992), each a result of major hurricane losses in those years.

Like the insurance industry, the Federal Emergency Management Agency (FEMA) has also seen a marked increase in the number of and costs of disasters since 1989 (U.S. Congress 1995). From 1985 through March 1996 FEMA declared 492 disasters (Fig. 2), of which 396 , or $80 \%$, were weather-related (fires excluded). During that period FEMA obligated $\$ 15.8$ billion for disasters of which $\$ 10.9$ billion, or $69 \%$, was for weather-related events. The Red Cross disaster fund shows a similar trend (U.S. Congress 1995). In only the first three months of 1996, FEMA declared more weather disasters (42) than in any previous year except 1992 (43) and 1993 (56). Of course, FEMA's disaster declarations also involve consideration of significant societal effects, in this case politics.

\section{Floods}

\section{a. Impacts}

Annual flood damages for the period 1903-97 (Fig. 3a), as tabulated by the National Weather Service (NWS), have been increasing steadily (using constant dollars). Flood-related fatalities in the United States (Fig. 3b) from 1913-94 have been high since the early 1970s (compared to the period prior to 1970) due to an increased frequency of years with high deaths. Of the annual deaths related to floods, $80 \%-90 \%$ are caused by flash floods and $40 \%$ of these "are related to stream crossing or highway fatalities" (Zevin 1994).
Why have these trends occurred? Some have speculated that more heavy precipitation is the cause (Karl and Knight 1998), while others point to increased societal vulnerability due to growth and flood policies. A definitive answer to this debate awaits further research (Pielke and Downton 1999, manuscript submitted to J. Climate). Events in recent years provide vivid evidence that people and property in the United States remain extremely vulnerable to floods. However, data are lacking (or unavailable) that would allow accurate and useful determination of the trends in and current level of societal vulnerability. A consequence of the lack of data on the areal extent of floodplains in the United States is that it is difficult to assess trends in and current levels of population at risk to flooding. One can easily hypothesize that increasing population and urbanization in the United States has led to a commensurate increase in population at risk. Yet one can also hypothesize that the various societal responses may have more than compensated for population growth and in fact fewer people are today at risk to flood impacts, particularly flash floods.

Accurate determination of property at risk to flooding faces many of the same obstacles as accurate determination of people at risk to flood impacts. Pielke (1999) found that there are relatively few systematic data collected on property at risk to flood impacts. The 1992 assessment of floodplain management in the United States found that "the actual amount of United States land in floodplains has not been clearly determined, nor has the amount of property and other economic investments at risk to flood 
FEMA Weather-Related Disaster Declarations (fres exriuded

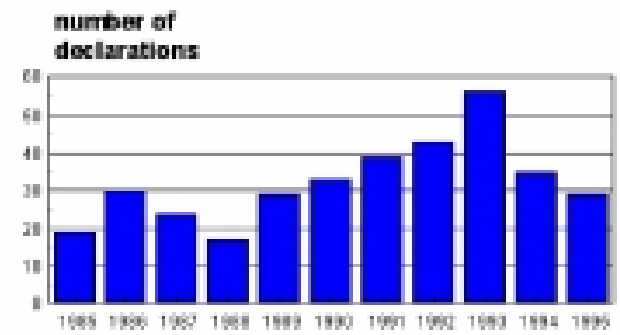

FEMA Weather-Related Disaster Declarations

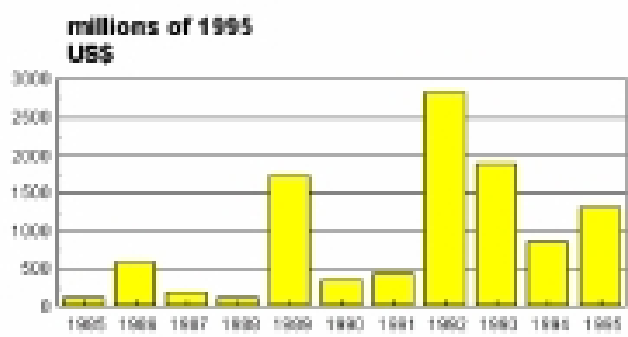

FIG. 2. The number of weather-related disaster declarations (top) and the funds obligated (bottom) by the Federal Emergency Management Administration for 1985-95.

impacts been firmly established" (FIFMTF 1992, ch. 3,1$)$. Again, the lack of data limits what can be said about trends in vulnerability to flooding. It is likely that the Federal Insurance Administration, which operates the National Flood Insurance Program, has in its records data on property at risk to floods for the communities that it has worked with since the early 1970s. However, these data have seen only limited use, for example, in determination of repetitive losses and substantial damages over $50 \%$, and have yet to be systematically assessed from the standpoint of trends in societal vulnerability to floods.

\section{b. Physical measures}

While excess precipitation is the fundamental cause of hydrologic floods, other factors play an important role, for example, antecedent soil moisture, rate of melt in snowmelt floods, and the physical characteristics (size, topography, control structures) of basins. However, most studies of climate trends have focused on precipitation only. Several recent studies have indicated a trend to more frequent heavy precipitation events. Karl et al. (1995a,b) found that 1-day heavy precipitation events exceeding 2 in. have made an increasingly large contribution to U.S. annual precipitation since 1910. Karl and Knight (1998) indicate a linkage between these precipitation changes and the record floods of the 1990s. Changnon and Kunkel (1995) examined trends in the frequency of 7-day heavy precipitation events for the midwestern United States for the period 1921-85. They examined events of 7-day duration because they found that these were closely related to 1 - to 5-yr recurrence hydrologic floods on small to medium-sized rivers. They found increases for a sizeable number of stations, particularly in parts of Illinois, Iowa, and Minnesota. There were very few stations with downward trends. Kunkel et al. (1997) expanded on this work and examined trends in 7-day heavy precipitation events for the entire country. They found (Fig. 3c) that there have been increases in the frequency of heavy events when averaged over the entire United States. Annual precipitation averaged for the entire United States also indicates that the last 15 years have generally been wetter than the long-term average. Figure $3 d$ shows the percent area of the United States experiencing severe soil moisture surplus using the Palmer Drought Severity Index, an extension of data presented by Karl et al. (1995b). Since about 1970, the percent area has been high relative to the long-term mean.

Recent studies of streamflow by Lettenmaier et al. (1994) and by Lins and Michaels (1994) have found upward trends consistent with the observed upward trends in heavy precipitation. Changnon and Kunkel (1995), in a study of flood peak stream flows for selected midwestern U.S. basins, found upward trends for many locations in the upper portion of the Mississippi River Basin. However, Lins and Slack (1999), in a comprehensive analysis of hydrologic floods in unmodified basins across the United States, found no statistically upward or downward trends in extreme flood frequencies or intensities during the twentieth century.

Although these studies are revealing, the extensive human modification of river basins during this century makes it very difficult to assess long-term trends in peak flows on major rivers on a national basis and relate this to flood damage. As an example, Fig. 4 shows the timing of major floods on the Mississippi River at St. Louis since 1840. Two measures are shown, peak stages (height of the river level) and peak discharges (volume of water passing). The development of a major levee system on the river over time has greatly influenced the stages by forcing the river to stay in its channel and rise higher and higher, relatively speaking. Peak stages (Fig. 4a) have been concentrated in the last 50 years. However, peak discharge (Fig. 4b) is less affected by human intervention in the basin's land use than the crest. Major floods, as measured by 
a)

US. Flood Darnages, $1903-1907$

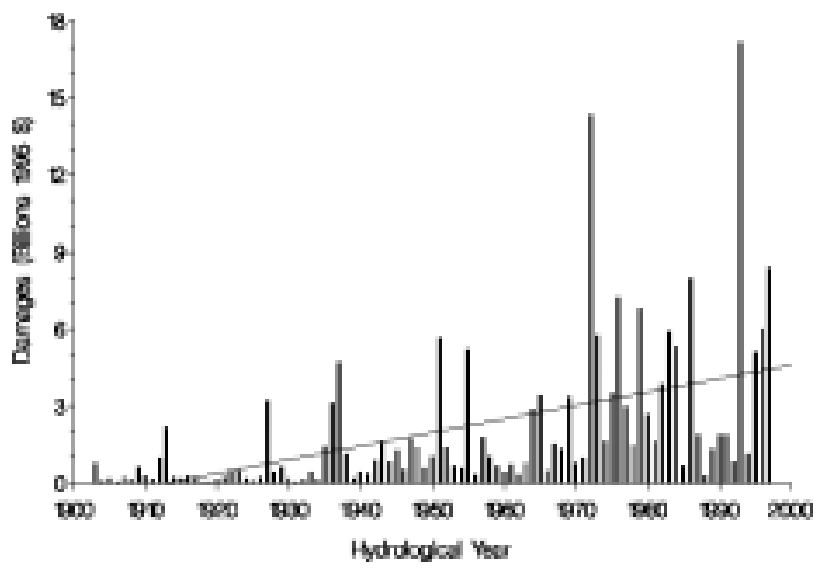

c)

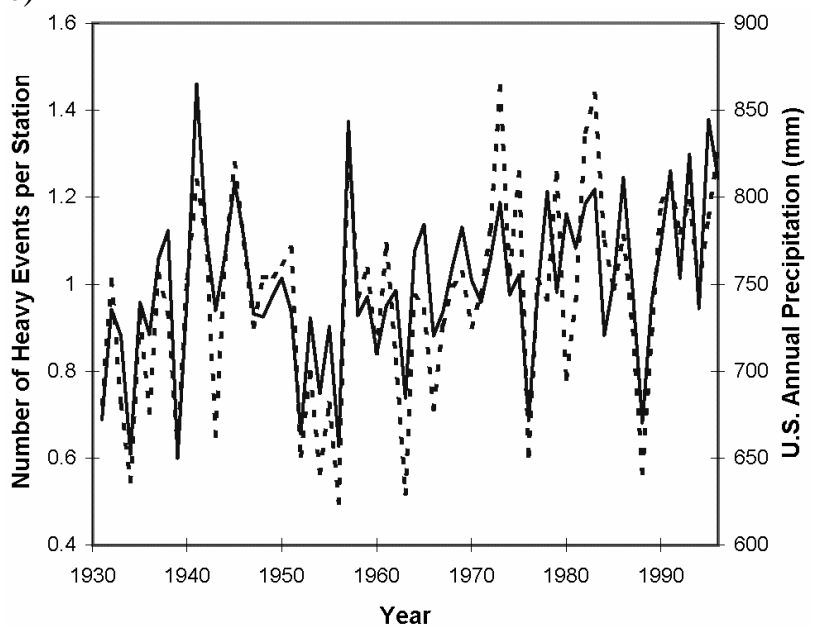

b)

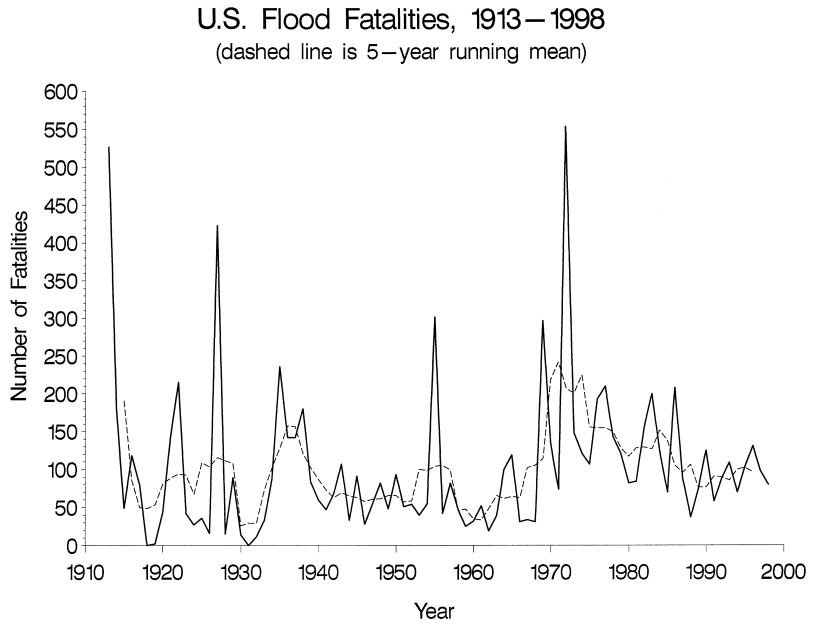

d)

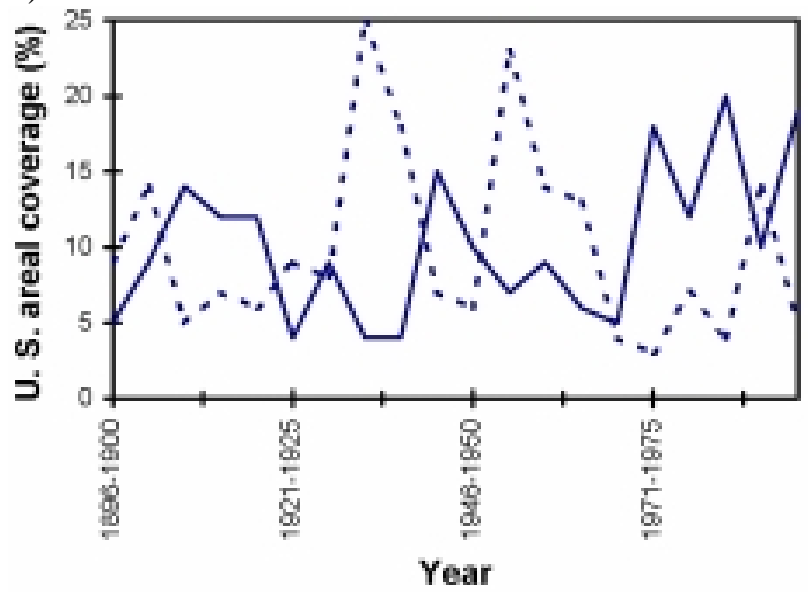

FIG. 3. Flood statistics: (a) annual values and linear trend for flood damages in the United States for 1903-97; (b) annual values (dashed line) and 5-yr average values (solid line) of flood-related fatalities in the United States for 1913-94; (c) frequency of heavy precipitation events (solid line) for the United States during 1931-96 (events are defined as periods when 7-day precipitation totals exceed the station-specific threshold for a 1-yr recurrence frequency) and annual values of average U.S. precipitation (mm) (dashed line); (d) percent area of United States with severe moisture surplus (solid line) and severe drought (dashed line) averaged over pentads for $1896-1995$.

the volume of water, have a very different temporal distribution. The largest flood on record, by this measure, occurred in 1844, followed by the floods in 1903 and 1993. More importantly, the temporal distribution of the major discharge floods reveals that they are well distributed over the $160-y r$ period, with no obvious long-term trend (Knapp 1994).

In sum, available data indicate that flood-related damage and deaths have increased in recent decades. There is also an increase in the frequency of heavy precipitation events and in the percentage of area experiencing excessively moist conditions. However, because of the limited nature of the impacts data, little can be said with authority about the relative contributions of physical forcing (i.e., increases in floodproducing precipitation) and changes in societal vulnerability as causes of the impacts trends.

\section{Hurricanes}

\section{a. Impacts}

Figure 5a shows total annual damage and casualties for the United States from 1900 to 1996 (Hebert et al. 1996). Loss of life has steadily decreased from the 1950 s to the 1980 s. By contrast, damages have in- 
a)

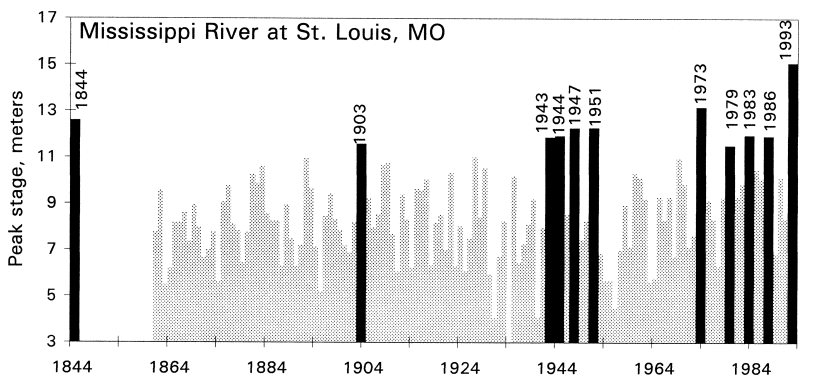

b)

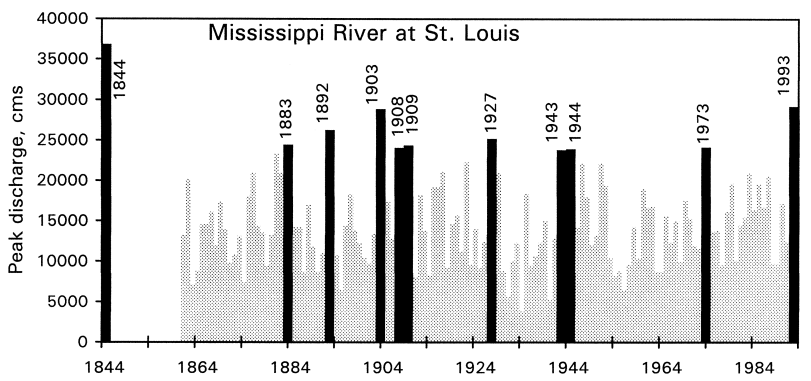

FIG. 4. Annual values of (a) the peak stage (m) and (b) the peak discharge $\left(\mathrm{m}^{3} \mathrm{~s}^{-1}\right)$ on the Mississippi River at St. Louis, MO, for 1844-1993 (from Knapp 1994).

creased substantially. A recent study (Pielke and Landsea 1998) used a methodology to "normalize" hurricane loss values to 1995 levels through adjusting not only for inflation, but also for growth in wealth and population in coastal areas. The resulting loss estimates suggest what the economic impacts would have been if each season's hurricane landfalls (1925-96) occurred in 1996 (Fig. 5b). For the 71 years used in the study, hurricanes caused $>\$ 346$ billion in aggregate losses, or an annual average of about $\$ 5$ billion, with a maximum of $>\$ 74$ billion in 1926 and numerous years with no reported damage. Of the 72 years, 35 years (about 50\%) had less than $\$ 1$ billion in damages. There were 19 years (about 25\%) with at least $\$ 5$ billion and 12 years (about 17\%) with at least $\$ 10$ billion. The 1940s and 1950s stand out as periods of significant normalized losses.

\section{b. Physical measures}

Landsea et al. (1999) found that there has been a detectable decrease in the number of landfalling intense hurricanes over the period 1944-96 (Fig. 5c). In addition, they found no significant trend in the intensity of hurricanes over this period. Because landfalling intense hurricanes are responsible for more than $80 \%$ of the normalized damages, this seems to be the best climatological measure to relate to impacts. It is important to point out that a single powerful storm in an otherwise quiet period of storm activity can yield large impacts, as Hurricane Andrew did in 1992. Thus, even in this case, there will not be a perfect correlation between trends in landfalling hurricanes and societal impacts.

In conclusion, the increase in hurricane damages over recent decades has almost entirely taken place during an extended period of no upward trend in hurricane frequencies and intensities (Landsea et al. 1996). This means that fewer storms are responsible for the increased damages, and these storms are no stronger than those of past years. Clearly, rather than the number of and strength of storms being the primary factor responsible for the increase in damages, it is the rapid population growth and development in vulnerable coastal locations (Pielke and Pielke 1997).

\section{Thunderstorm-related losses}

\section{a. Impacts}

Thunderstorms are a fundamental part of the nation's climate, producing between $15 \%$ (West Coast) and $70 \%$ (high plains) of the average precipitation across the nation (Court and Griffiths 1986). Thunderstorms also produce five weather phenomena that damage property and crops and kill and injure humans and livestock: lightning, tornadoes, high winds, heavy rainfall (and flash floods), and hailstorms (Myers and Etkin 1999). Thunderstorm-related damages occur across all parts of the nation and are common each year, causing $45 \%$ of all weather-related insured property losses in the nation. Annual lives lost due to lightning, as reported by the National Oceanographic and Atmospheric Administration show no trends, up or down, since 1975.

Thunderstorm-produced property losses recorded by the insurance industry offer a useful measure of the trends in the impacts of all five thunderstorm-related phenomena treated collectively. Figures $6 \mathrm{a}, \mathrm{b}$ present the frequency of thunderstorm-caused catastrophes resulting in more than $\$ 100$ million in losses for the southeastern United States (Texas to Virginia) and the central United States (Nebraska to Ohio) (Changnon et al. 1996). The 5-yr values for both areas show an early peak in 1950-59, followed by 20 years of lower values, and then ever-increasing catastrophic storms into 1990-94. The national frequency of catastrophes 
caused by thunderstorm-related conditions for the 1950-94 period appears in Fig. 6c. These show everincreasing values from 25 in 1950-54 to 153 in 199094.

\section{b. Physical measures}

Figures $6 \mathrm{a}, \mathrm{b}$ also present $5-\mathrm{yr}$ values of the number of days with thunderstorms for the southeast and central U.S. regions, as measured at weather stations of the NWS. These thunder-day values are high in the early period, 1950-59, declining as did the thunderrelated catastrophes to lower values in the $1960 \mathrm{~s}$ (Gabriel and Changnon 1989). However, the thunderday values had a minor peak in 1970-79 and since have declined (Changnon 1997). Thus, the recent peaking of thunderstorm-caused catastrophic storms is not found in the frequency of thunderstorms from NWS data, and there is general disagreement in their temporal distributions after 1970. The national average number of thunderstorm days (Fig. 6c), based on data from 75 NWS stations distributed across the nation, show fluctuations with time. Values were highest in 1950-54, decreasing to lower values in recent years. The curves on Fig. $6 \mathrm{c}$ suggest that the increase in catastrophes and the losses they represent over time are not a result of shifts in thunderstorm conditions but rather a function of other factors such as increasing population and the associated property at risk to such events.

\section{c. Hail impacts}

The crop-hail insurance industry has kept detailed records on all insured losses in the nation since 1948, including annual losses, liability, and the loss cost, a normalized expression involving loss and liability coverage used to enable an equitable comparison of outcomes between years (Crop-Hail Insurance Actuarial Association 1978). In a study of annual insurance crop-hail loss values for Texas, Changnon (1996) found that losses have been increasing from 1970 to the early 1990s, reaching a peak of $\$ 54$ million in 1992. However, the loss costs, the normalized expression, show no upward trend, but do show more interannual variability since about 1975 . Temporal fluctuations in hail losses exhibit great spatial variations across the nation (Changnon 1977). The loss cost data for Illinois (Fig. 7a) show that loss cost values were at their highest point in the early 1950s. Since then, there has been a general decrease with the 1990s having the lowest values of the last 50 years. On a national basis, crop-hail insurance data show a steady climb in losses from $\$ 40$ million in 1948 to nearly a)

\section{Hurricane Damage and Deaths in the Twentieth Century}
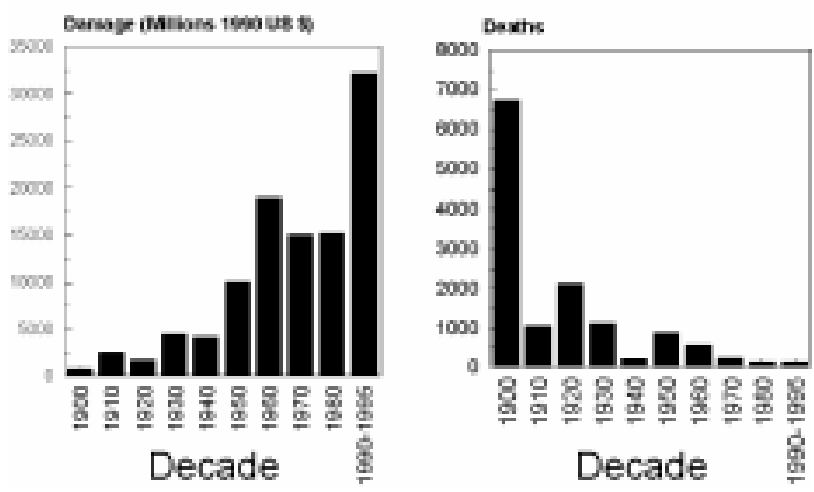

b)
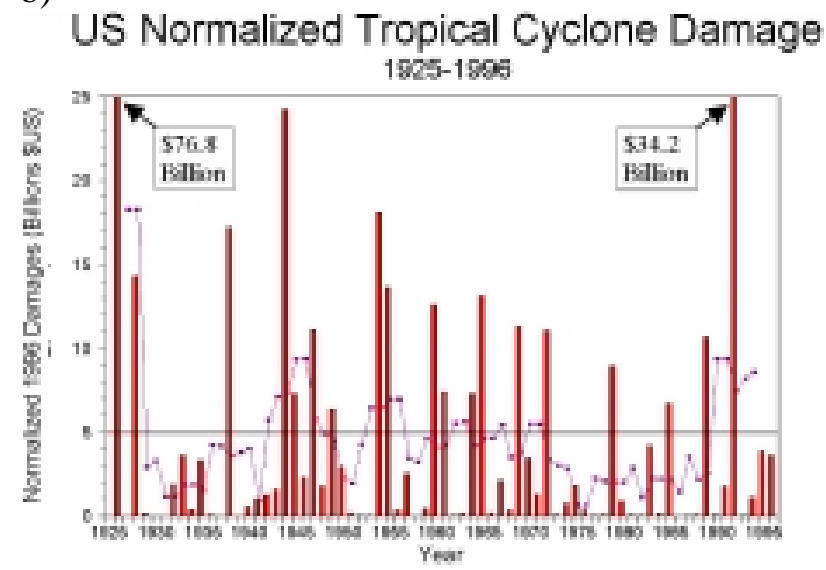

c)

\section{Atlantic Intense (Major) Hurricanes 1944-1996}

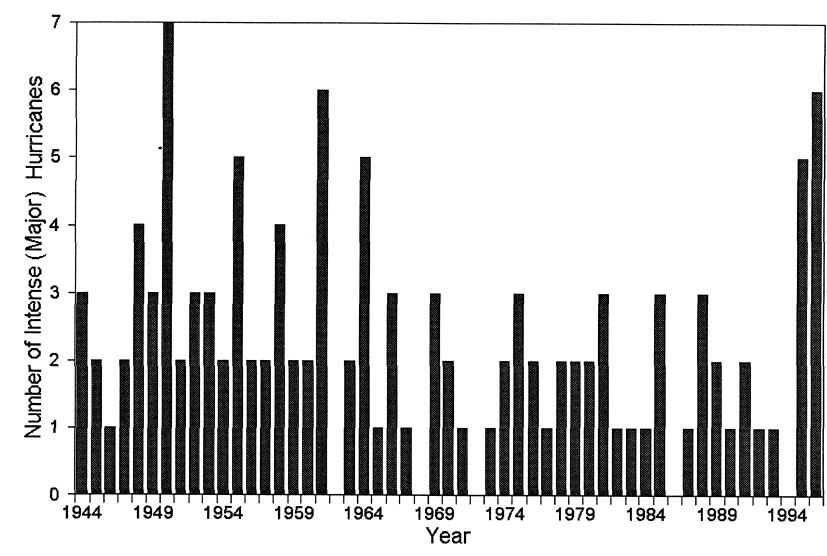

FIG. 5. Hurricane statistics: (a) decadal totals of damages (left graph) and fatalities (right graph) due to hurricanes for 1900-95; (b) annual hurricane damages normalized for inflation, wealth, and coastal population for 1925-96 (from Pielke and Landsea 1998); (c) annual number intense U.S. landfalling hurricanes (courtesy C. Landsea). 
a)

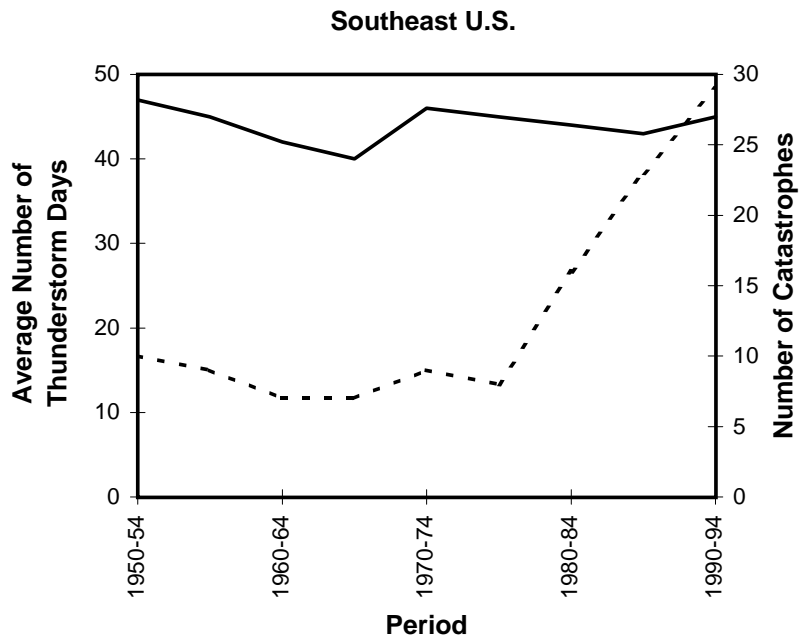

b)

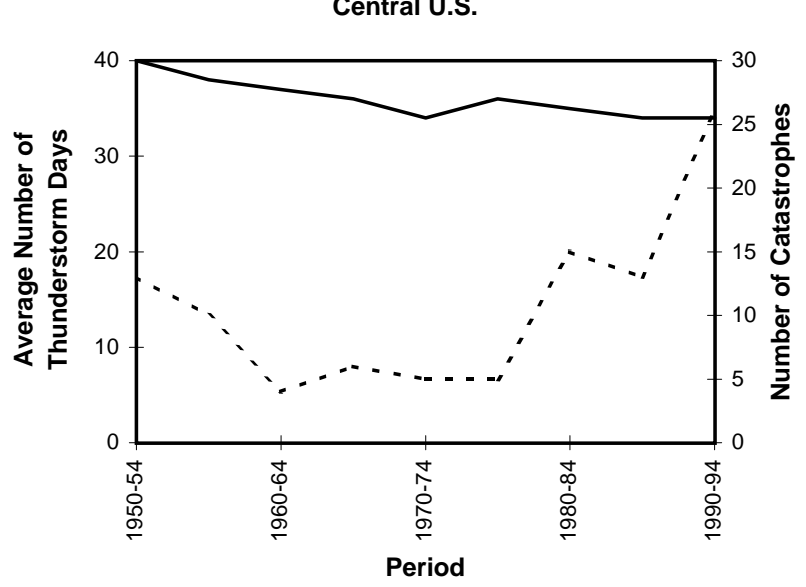

c)

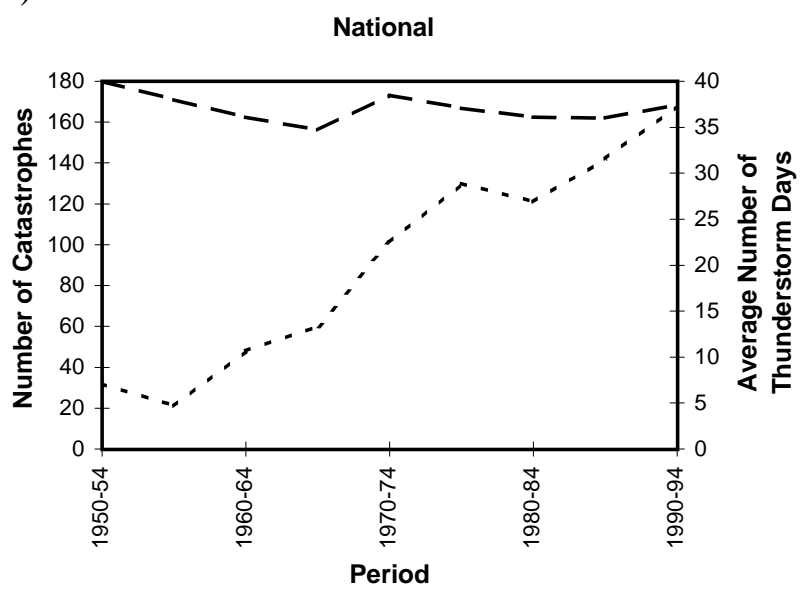

FIG. 6. Thunderstorm statistics including pentadal values of thunderstorm days (solid line) and number of catastrophes (dashed line) caused by thunderstorms during 1950-94 in the (a) southeast and (b) central United States; (c) number of catastrophes caused by thunderstorm conditions (short dashed) and national average frequency of thunderstorm days (long dashed).
\$400 million in 1992 and 1994 (Fig. 7b). However, the normalized loss expression, loss cost, shows essentially a flat temporal distribution with multiyear peaks in 1954-56 (\$3.27), 1961-63 (\$3.38), and 1992-94 (\$3.25). Hail produces both crop and property damage. The property losses from hail in property insurance catastrophes between 1950 and 1994, after normalization, show (Fig. 7c) wide temporal fluctuations with peaks early (1950-54 and 1960-64) when crop losses also peaked. In general, property hail losses show a slight downward trend similar to the crop-hail losses. The number of hail-induced catastrophes (Fig. 7c) show a generally flat temporal distribution with 20 to 30 catastrophes in most pentads.

\section{d. Physical measures of hail}

In 1896 the U.S. Weather Bureau began to compile records of all incidences of hail at all weather stations and these serve as the basis of comparison with the crop loss data. The Illinois hail days from 190595 show no trend from 1905 to 1945 (Fig. 7a), followed by a statewide peaking of hail during 1950-65, followed thereafter by a continuing decline, reaching century lows in 1991-95 (Changnon 1995). The loss cost values for 1946-95 in Illinois show a strong relationship with hail days (correlation coefficient of +0.89), peaking in 1951-55 and being least in 199195. Results for hail days in Nebraska showed similar results with a midcentury peak and a good relationship to loss costs (Changnon et al. 1996b). An important finding from these results is that hail losses, when adjusted for shifting conditions (inflation and coverage), relate well to the incidence of hail days as derived from a noninsurance source, the National Weather Service.

\section{e. Tornado impacts}

Tornadoes are a product of thunderstorms, and most tornadoes are small in scale (covering less than a square mile) and are extremely infrequent events at any given location. Records of tornadoes have been derived from visual observations of tornado funnels, generally by untrained observers, and by damage surveys conducted when tornadoes were sufficiently devastating to get such attention. A tornado can go undetected if there is no one present to see the funnel, and hence their reporting is a function of population density. For these reasons, the historical data on tornadoes is suspect (Changnon 1982; Grazulis 1993a; Schaefer et al. 1993; Ostby 1993). Figure 8a illustrates that the number of deaths due to tornadoes has de- 
creased from the 1950s to the mid-1990s (Grazulis 1993b, 1997), perhaps reflecting the effects of improved storm warnings and detection on public safety.

\section{f. Physical measures of tornadoes}

Figure $8 b$ illustrates how national tornado incidences have steadily increased with time from 1953 to present (Grazulis 1993b, 1997). However, note that the number of days with tornadoes (lower line) has remained essentially unchanged since 1960. This difference illustrates the effect of population density increases and public awareness on the detection and reporting of tornadoes, not a physical change in events (Ostby 1993). Figure 8c shows the distribution of the annual number of tornadoes resulting in at least one fatality (Grazulis 1993b, 1997). No trend exists for the 1953-96 period, although there have been occasional years with large values when numerous outbreaks of large tornadoes occurred. In summary, available tornado data on deaths and damages show a general decrease in deaths and large variability in damages (Grazulis et al. 1998). The number of thunderstorm-caused catastrophes show a fluctuating increase with time (Fig. 6c), whereas hail catastrophes (Fig. 7c) and the number of tornadoes causing deaths (Fig. 8c) do not show comparable temporal trends. This likely results because damaging hail swaths and tornado paths are very small phenomena, constitute only a third of all thunderstorm-caused catastrophes, and the preferred locations of most potentially damaging hail and tornado events are in areas of low population density, mainly the Great Plains. a.

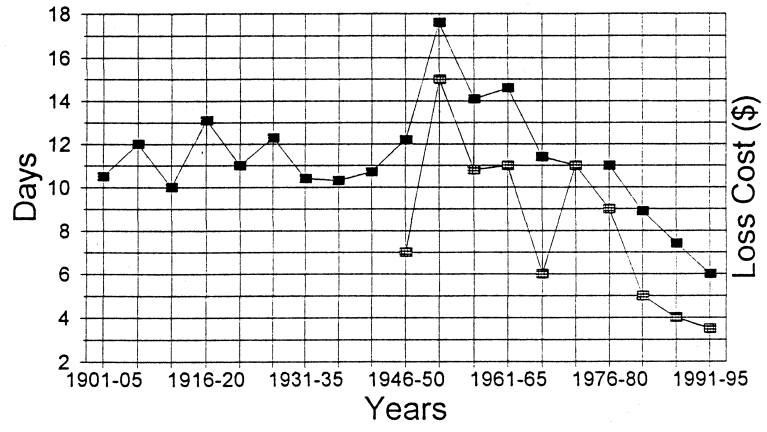

b. Losses Liability

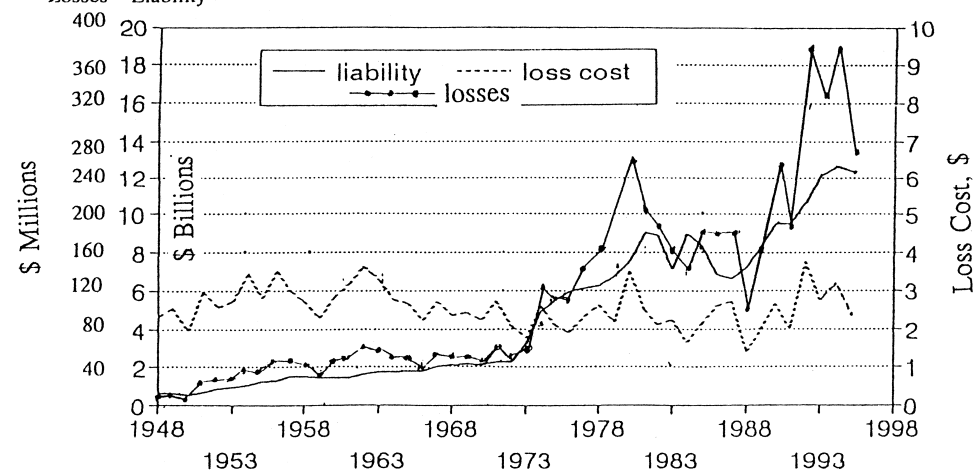

c.

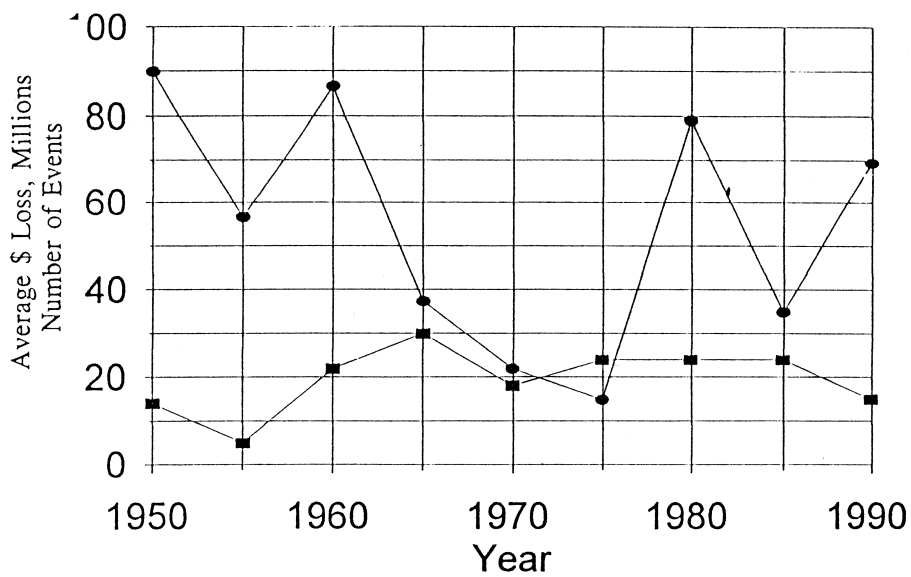

FIG. 7. Hail statistics: (a) pentadal values (light squares) of loss cost (194695) and state-averaged number (dark squares) of hail days (1901-95) for Illinois; (b) annual values of losses, lost costs, and liability from crop-hail insurance in the United States during 1948-95; (c) pentadal values of property insurance catastrophes due to hail and wind during 1950-94 for the United States, including the frequency of events (squares) and the average 5-yr dollar loss per event (circles).

\section{Winter storms}

\section{a. Impacts}

Losses associated with winter storms have not been systematically compiled, limiting what can be concluded about trends in impacts (Kocin et al. 1998) and the link to climatic measures. Weather-related losses to the insurance industry during the first quarter of each year (January-March) 1976-96 reveal increasing losses during the 1990s (Fig. 9a). Examination of a 46-yr record of property-insurance catastrophes for 1949-94 reveals that no winter storms qualified as catastrophes during the 1949-74 period. However, beginning in 1975 , a few winter storms produced sufficient damages to qualify as catastrophes. The 
a)

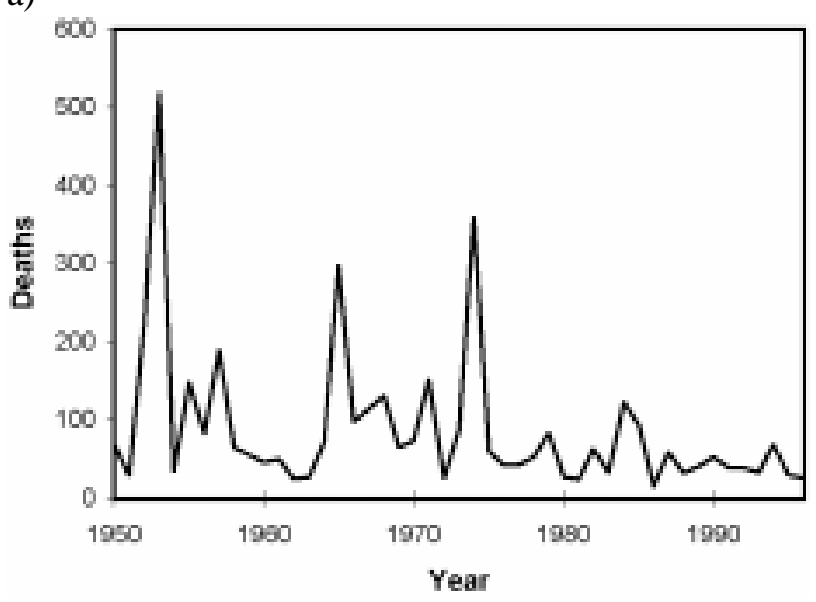

b)

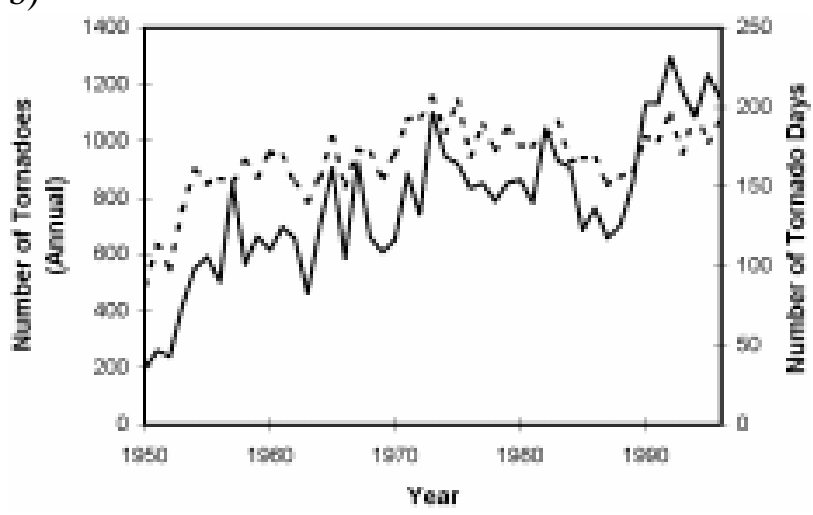

c)

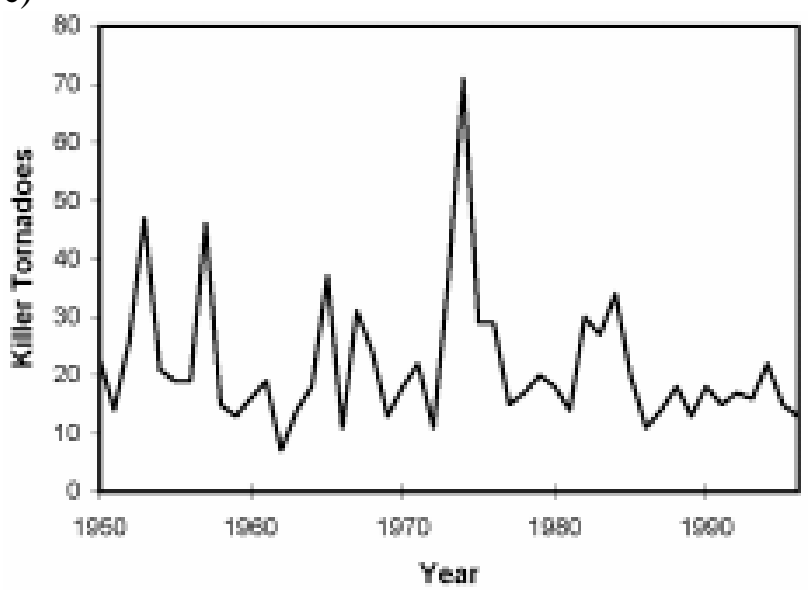

Fig. 8. Tornado statistics: (a) annual number of deaths due to tornadoes in the United States; (b) annual values of number of tornadoes (solid line) and tornado days (dashed line) for the United States (1953-96); (c) annual number of tornadoes causing fatalities for the United States (1953-96).

number of catastrophic winter storms for the subsequent 5-yr periods have been as follows: 1975-79 $=6,1980-84=15,1985-89=12$, and $1990-94=21$
(Changnon et al. 1996b). The shift in catastrophes of all types is strongly correlated to growth in population and demographic shifts, and much of the national increase in winter storm catastrophes occurred in the nation's coastal regions. The losses due to catastrophic severe winter storms have increased with time.

\section{b. Physical measures}

Extratropical cyclones (ECs) are primarily responsible for the damaging phenomena that result in winter season insurance losses. The U.S. east coast region is a favored area for the development of very strong ECs because of geographic and topographic influences (Kocin and Uccellini 1990). The high population density and extensive coastal development make this region particularly vulnerable to damage from high winds, coastal flooding, heavy snow, and icing. The frequency of strong, damaging east coast ECs (Fig. 9b), termed nor'easters, has been highly variable since 1965 with very high values from 1968-72 and 1988-92 (Davis et al. 1993). Although these data have not been updated to include the years after 1992 when damages rose (Fig. 9a), there have been several notorious events such as the March 1993 "Storm of the Century" (Kocin et al. 1995), suggesting a continuation of the high frequency. One of the most damaging aspects of nor'easters is coastal flooding caused by strong onshore wind flow. The frequency of high water levels has steadily increased from the early 1900s into the 1990s and is attributed to sea level rise (Zhang et al. 1997). Thus, observed increases in damage may not only be due to an increased frequency of strong nor' easters, but also to a more vulnerable coastline.

A study of winter storms over the Great Lakes basin (Angel 1998) identified "strong cyclones" as those capable of producing damages to shipping and shoreline facilities. Figure $9 \mathrm{c}$ presents the annual frequency of the strong cyclones over the Great Lakes basin from 1900 through 1996, and shows a slow but general increase from 1900 until the 1960s. Thereafter the frequency declined somewhat. By contrast, inflationadjusted damages due to winter storms on the Great Lakes from 1949 to 1990 (Angel 1995) peaked in the 1980s. This peak is partly attributable to high water levels during the 1980s and may also be due to population increases which that study did not take into account.

To summarize, the increase in losses is most likely associated with both societal factors and climatic factors, but further research is needed to discern the relative contribution of each. 


\section{Drought}

a. Impacts

Drought has a broad range of impacts. There is no comprehensive database of losses that can be used to assess long-term trends. We must rely instead on certain case studies (e.g., Riebsame et al. 1990). Therefore, caution is advised in drawing broad conclusions from the following selected examples of drought effects on crop yield and water resources. Figure 10a shows the annual Illinois corn yield values for 1930-96 expressed as a percent of an average yield expected with normal weather, following the yield adjustment procedures of Thompson (1969). This approach attempts to remove the yield trends due to changes over time from nonclimatic factors such as improved hybrids, new fertilizers, planting density, and shifts in land management practices. The corn yield distribution shows the marked effect of multiple droughts in the 1930 s, those of the 1950s, and the sporadic one-year droughts in 1980, 1983, and 1988. Inspection of the distribution also shows a period of low year-to-year variability in yields from after the droughts of the $1950 \mathrm{~s}$, lasting until the sporadic droughts of the 1980s. Greater year-to-year variability in corn yields existed from 1930 to 1955 and from 1980 to 1996, but no longterm trends of lesser or more variability are evident.

The impact of drought on the levels of Lakes Michigan-Huron is shown in Fig. 10b for 1860-1996 (Changnon et al. 1994). Lake levels at a given time reflect the amount of basin precipitation over the preceding 1-3 years. The temporal distribution of lake levels shows that two multidecadal wet periods occurred, one from 1860 to 1885 , and another from the 1970 s to the 1990s. Prolonged low precipitation over the basin began in the 1890s, leading to ever-decreasing lake levels up through the 1930s. Thereafter, precipitation increased except for a short but severe drought in the late 1950s-early 1960s. This 140-yr record suggests a long-term U-shaped distribution of precipitation over time with wetter conditions since 1940.

\section{b. Physical measures}

Crop yields are related to weather in complex and not completely understood ways. One important measure for corn is July precipitation, which has a high correlation with Illinois corn yields (Fig. 10a). This measure has become more variable in the last 15 years but does not exhibit an obvious trend. Temporal graphs of the Standardized Precipitation Index, one index of drought intensity, for each season since 1911 in the a) Jan - Mar Insured Property Losses 1976-1996

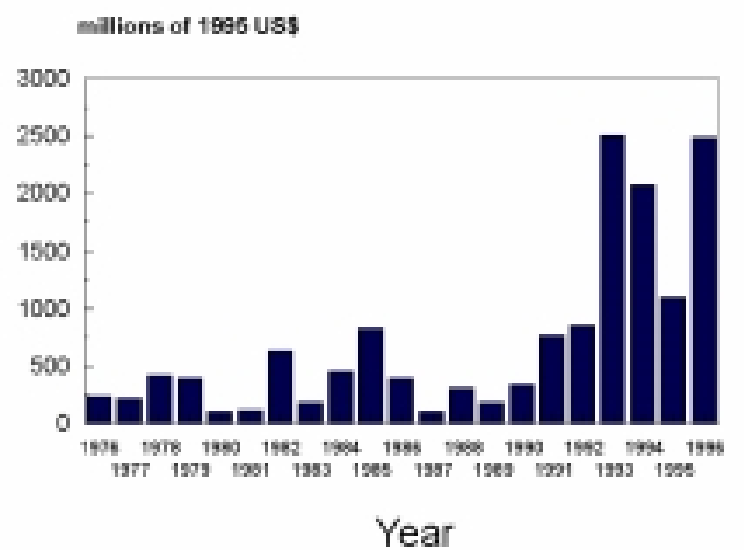

b)

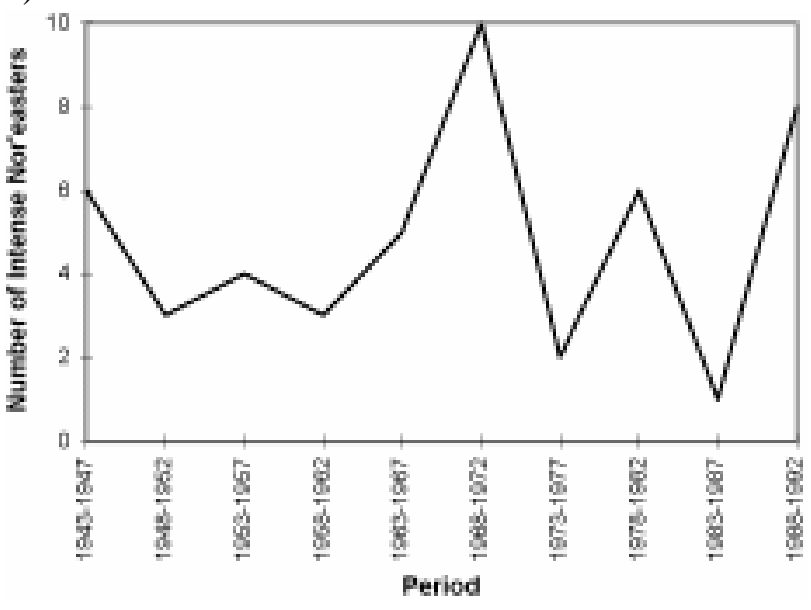

c)

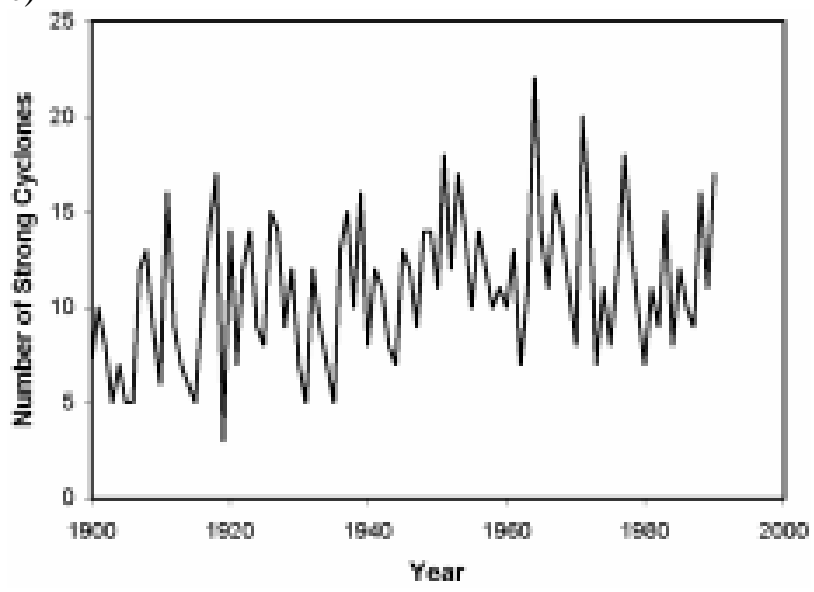

FIG. 9. Winter storm statistics: (a) weather-related insured property losses during Jan-Mar, 1976-96, for the United States; (b) number of intense nor'easters (from Davis et al. 1993); (c) annual number of strong extratropical cyclones in the Great Lakes basin, 1900-90 (from Angel 1996). 
a)

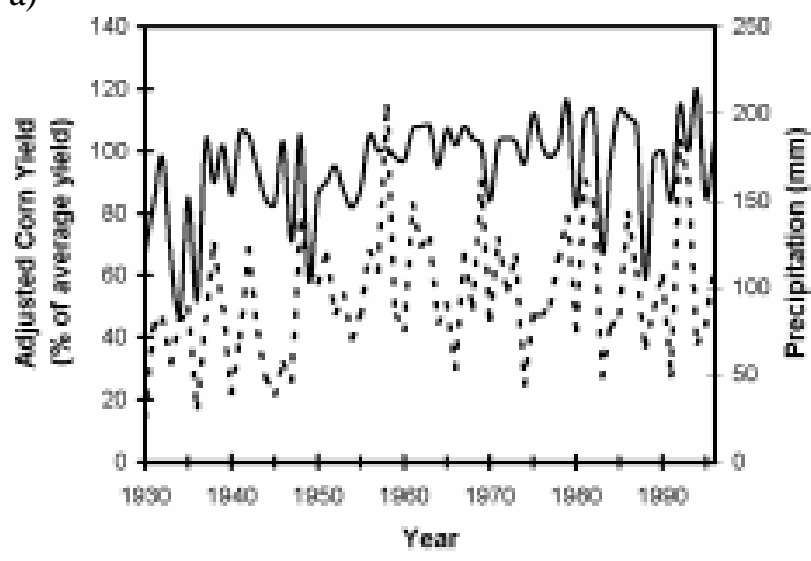

Fig. 10. Drought statistics: (a) annual Illinois corn yield (dark line), expressed as the percentage of an average yield adjusted for technology advances following the method of Thompson (1969), and the state-averaged July precipitation $(\mathrm{mm})$ (dashed line); (b) 5-yr moving average of the level of Lake Michigan-Huron, 1860-1997 (updated from Changnon et al. 1994).

central United States are presented in the Fig. 10c (Edwards et al. 1997). Values below the zero line are a measure of droughts and the greater the negative value, the greater the drought intensity. The autumn graph shows no droughts, since 1963, but the distribution for the other three seasons show droughts scattered randomly throughout the 1911-95 period.

Figure 10d shows, for the 1895-1990 period, the annual extent of drought for the Mississippi River basin, expressed as the percent of the basin experiencing severe to extreme drought conditions (Riebsame et al. 1990). The periods of drought have had a sporadic distribution, centering on severe hydrologic droughts in the 1930s and again in the 1950s-early 1960s. No distinct time trend is evident. Comparisons of this distribution with that for major floods at St. Louis (Fig. 4) reveals, as expected, an inverse relationship. That is, the major floods on the river occurred in the years when very little of the basin was in drought.

Droughts can be measured physically through precipitation deficiencies or indices, but are often defined through the impacts they create in the hydrologic cycle and in turn on socioeconomic activities. An investigation of hydrologic droughts across the entire nation from 1895 to 1990 is shown in Fig. 10e (Riebsame et al. 1990). The hatched areas are based on hydrologic drought indices with values exceeding 3 meaning that streamflows were significantly decreased. Nationally, b)

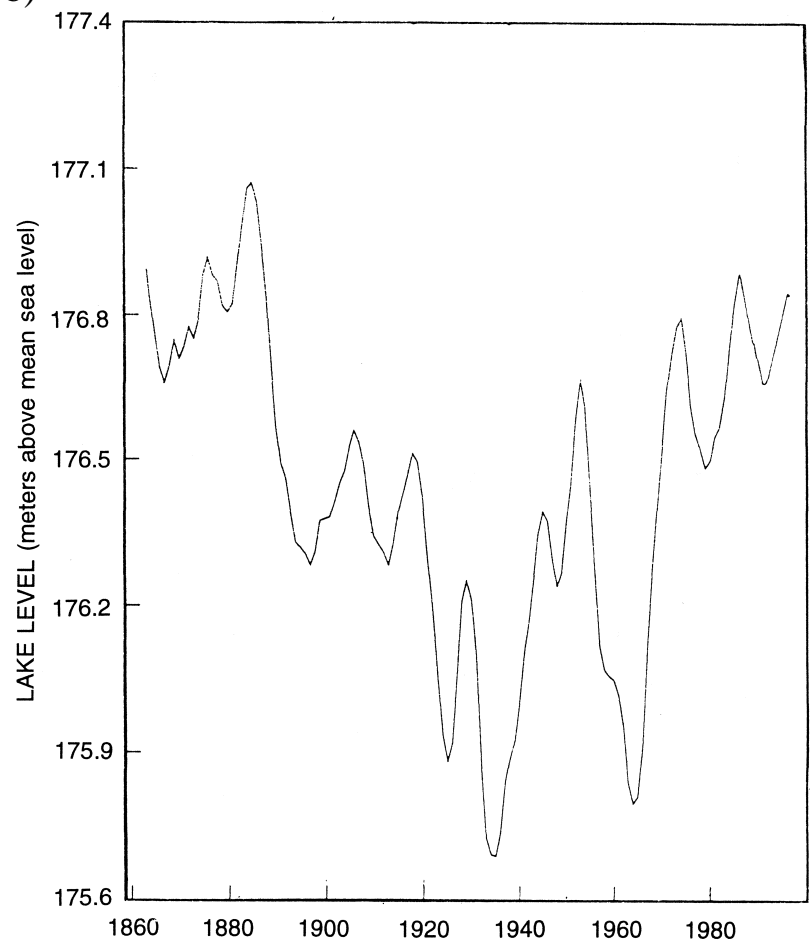

these reflect the prolonged hydrologic drought of the 1930s, and also reveal that the hydrologic drought of the 1950s was more severe on water supplies than that of the 1930s. All other hydrologic droughts of the past 100 years were of shorter term (1-2 years) and were scattered throughout the entire 1895-1990 period. There is no indication of a shift in hydrologic drought frequency over time. The two major events of the midcentury dominate the distribution. This behavior is also seen in the Palmer Drought Severity Index (Fig. 3d).

\section{Extreme heat and cold}

\section{a. Impacts}

Extremes of temperature have well-known impacts on human health. There are indications that the number of heat-related deaths in the United States have been increasing in recent years (Changnon et al. 1996a), but heat-related death tallies are suspect (cf. Donoghue et al. 1997). Ellis (1972) showed that the hot summers of 1952-55 each resulted in more than 500 deaths, with $>5000$ heat deaths estimated in 1963 and 6700 in 1966 (Avery 1985). More than 15000 heat-related deaths are estimated to have occurred in the heat waves of 1980 (U.S. Senate Special Committee on Aging 1983). Unfortunately, statistics on hu- 
c)
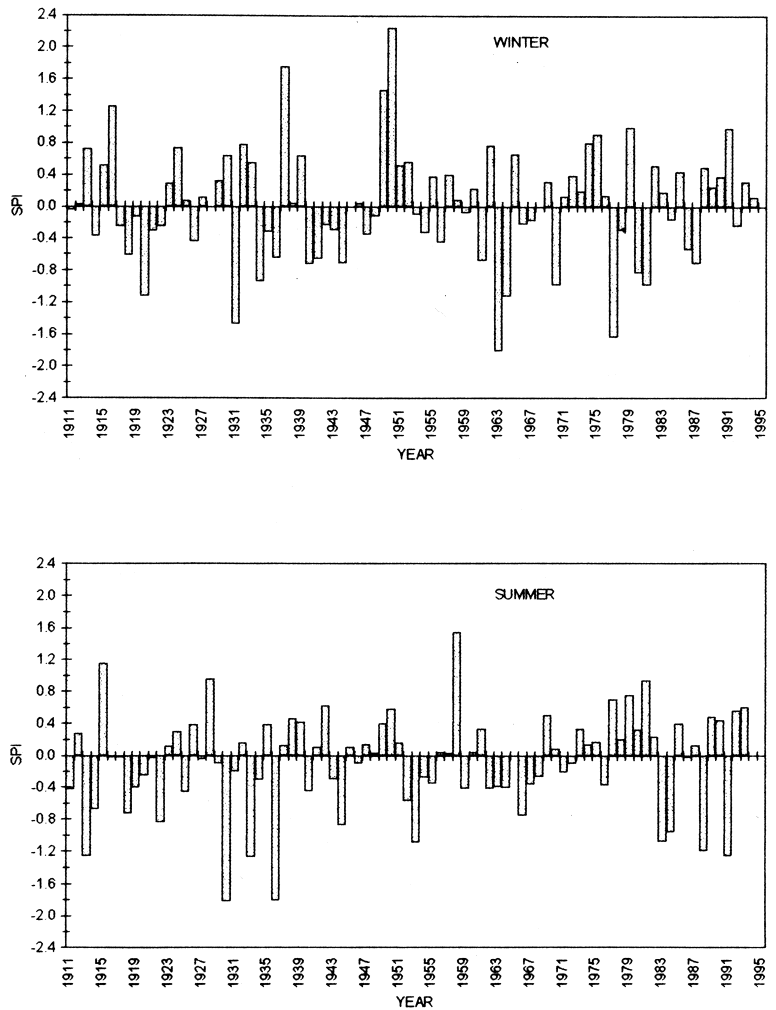

d)

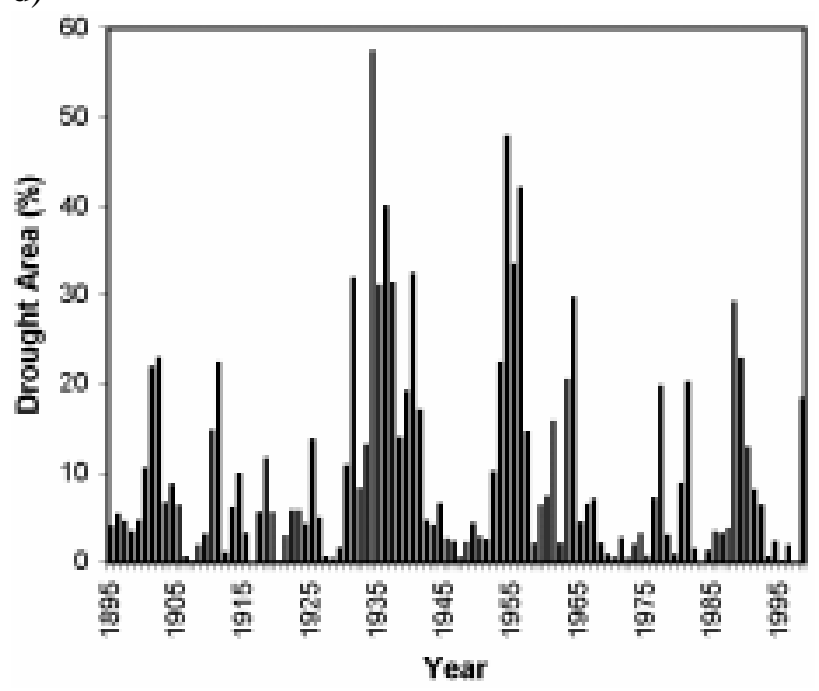

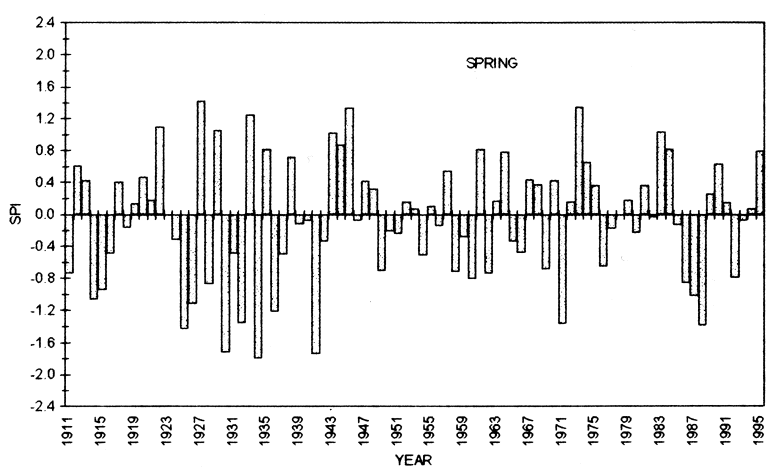

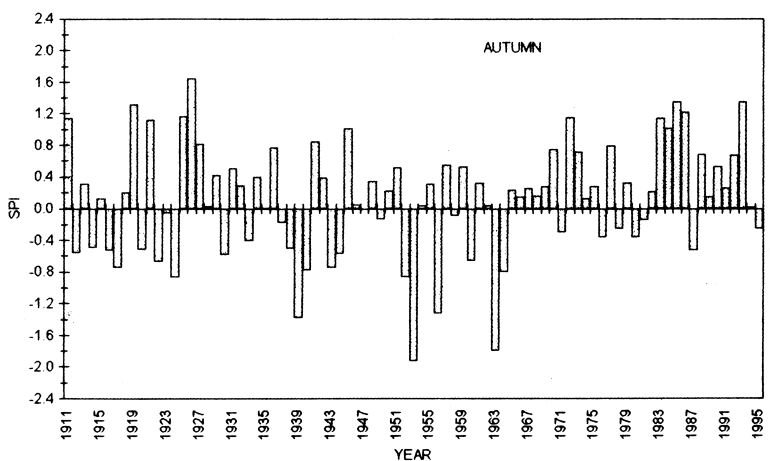

e)

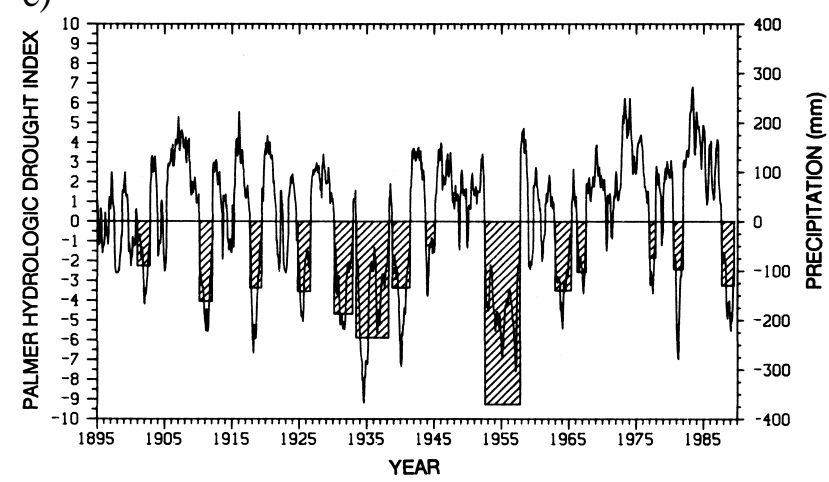

FIG. 10 (continued). (c) Average 3-month Standardized Precipitation Index for the central United States for the four seasons, 191195 (from Edwards et al. 1997); (d) annual values of the percent of the Mississippi River Basin with severe to extreme drought (from Riebsame et al. 1991); (e) Palmer Hydrological Drought Indices (PDHI) calculated using area-weighted total precipitation and temperature for the United States. Accumulated national average total precipitation deficiencies during major droughts (PDHI < -3 ) are given by the hatched rectancles using the right-hand scale. The length of major droughts is depicted by the width of the rectangles along the time axis (from Riebsame et al. 1990).

man deaths caused by heat can be biased by many factors and accurate numbers are usually not available except under isolated circumstances of major heat extremes and when special studies are conducted.
Statistics based on identification of heat as the cause of death by a medical examiner are usually much lower than statistics based on comparison of overall death rates. For example, the Center for Disease Control 
(CDC) reports 1678 deaths in 1980 (Parish 1997), based on medical examiner identification; far fewer than the 15000 reported in congressional hearings.

The number of deaths due to extreme cold during the 1979-94 period varied from 267 deaths in 1992 to a high of 524 deaths in 1989, based on statistics from the CDC. The time distribution over this brief period does not suggest any obvious trend.

Extremes of temperature also cause losses to crops and property. Rogers and Rohli (1991) performed a study of winter freezes that damaged Florida citrus areas. They found that a cluster of severe freezes has occurred since the late 1970s. This recent cluster is the most frequent occurrence of freezes since the late nineteenth century. They identified six major freezes during 1977-89. During the earlier part of the twentieth century, severe freezes occurred only about once per decade. This series of freezes resulted in a significant decrease in the production of citrus (Miller 1988). National crop losses due to extreme cold vary widely between years, with damages being as low as $\$ 690000$ in 1988 and as high as $\$ 736$ million in 1989. During the 1975-95 period, the annual losses formed a Ushaped distribution with large losses in the late 1970s and large losses again in 1989-93 period. Property losses due to extreme cold, such as damage to frozen pipes, also vary widely between years. In the late 1975-95 period some years had no reported damages, whereas \$164 million in damages occurred in 1994. The values of loss do not indicate an upward or downward trend since 1975 .

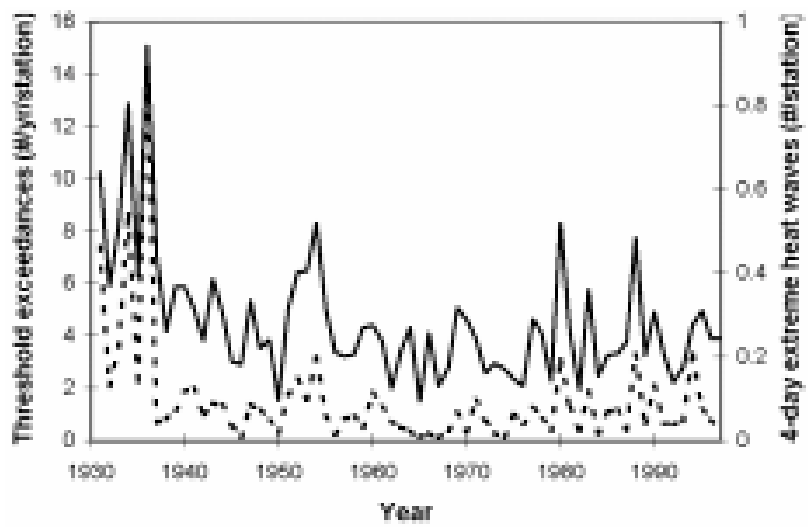

FIG. 11. Number of days with a maximum temperature above the threshold for a $1.5 \%$ daily exceedance probability (dark line) and the number of heat waves of 4-day duration with an average temperature exceeding the threshold for a 1 in 10 year recurrence (dashed line). Each curve represents an average of 876 long-term stations.

\section{b. Physical measures}

Kalkstein and Davis (1989) determined threshold temperatures, for 25 U.S. cities, above which mortality rises significantly. A comparison of each city's threshold with its daily temperature climatology indicates that these thresholds are exceeded on 5-10 days per year on average, or a daily probability of exceedance of about $1.5 \%-3 \%$. Using the $1.5 \%$ daily exceedance probability threshold, the number of exceedances per year was determined for 876 U.S. stations with long-term temperature records for the period of 1931-97. Figure 11 shows the annual number averaged for all stations. High numbers of exceedances occurred in several years during the 1930s, with 1936 recording the highest number. Since the 1930s, there is no indication of an upward or downward trend.

These temperature thresholds represent the minimum value for a detectable effect on death rate. However, the bulk of heat-related deaths occur in a small percentage of years with extreme heat, the 1995 heat wave being a prominent recent example. Kunkel et al. (1996) presented statistics on the 11 most intense 4-day heat waves at Chicago between 1901 and 1995, and ranked them according to peak temperature. Inspection of their distribution over time reveals that many occurred in the 1930s-40s (6), with only isolated occurrences in early decades (1901 and 1916), and in recent years (1988 and 1995 with 3). A trend is not indicated and the dominant feature is the midcentury peak of six heat waves. It is important to assess the relationship of these intense heat waves against lives lost to heat stress. The rank order of the top five heat waves in Chicago and the deaths caused by heat are as follows: 1) 1936 with 297 deaths, 2) 1934 with 213 deaths, 3) 1995 with 525 deaths, 4) 1988 with 382 deaths, and 5) 1931 with 169 deaths. This shows that the two recent heat waves had disproportionately more deaths than did the more intense heat waves in the 1930s. This increase has been attributed to changing lifestyles, a growing elderly lower income population that suffers the most from heat stress and is largely unable to afford air conditioning, and other societal factors (Changnon et al. 1996a). This suggests that the apparent increase in heat wave deaths in the United States during recent decades is related to societal factors. The regional assessment of heat deaths by Kalkstein and Davis (1989) showed marked regional differences in cities across the United States with a greater tendency for heat-caused deaths in the older cities of the northern United States where human and 
urban adaptation to infrequent heat waves is less than in southern cities where high temperatures are more common. Use of air conditioning has increased with time and decreased heat deaths, and Kalkstein (1995) estimated that air conditioning led to a $21 \%$ reduction in heat deaths in New York City from 1964 to 1988. However, analysis of heat deaths in the 1995 heat wave in Chicago revealed that many who perished in the inner city were without air conditioning (Changnon et al. 1996a).

To assess whether there are any trends in the most extreme heat waves, we identified heat waves of 4-day duration exceeding a temperature threshold for a 1 in 10 year recurrence, using the aforementioned 876 long-term stations. The annual frequency, averaged for all stations, is shown in Fig. 11. The dominant feature is the high frequency during the 1930s. The years with the highest frequency since then were 1954, 1980, 1988, and 1994. The frequency for 1995 is not particularly high because that event was of relatively small spatial extent; unfortunately, the event was most intense over one of the nation's largest population centers. Overall, there is no indication of a trend. Another recent study (DeGaetano 1996) of trends in extreme temperatures for the northeast United States for the period 1951-93 found a statistically significant decrease in the number of days with temperatures exceeding $95^{\circ} \mathrm{F}$. He also found a general increase in the number of days with temperatures below $0^{\circ} \mathrm{F}$; however, this trend was not statistically significant. By contrast, Balling and Idso (1990) studied trends in extreme high summer temperatures in the United States for the period 1948-87. They found that the frequency had increased.

Figures 12a,b present the historical distribution of the Winter Disruptive Index, defined by excessively low daily and winter season temperatures and snowfall combined (Nese and Knight 1997). Indices of +3 represent typical winters, whereas winters with a value

FIG. 12. Cold wave statistics: Winter Disruptive Index based on extreme low temperatures and snowfall, following Nese and Knight (1997), for (a) New York City, and (b) Helena, MT; (c) winter freezing indices for St. Louis, 1940-88; (d) number of days with a minimum temperature below the threshold for a $98.5 \%$ daily exceedance probability (solid line) and the number of cold waves of 4-day duration with an average temperature below the threshold for a 1 in 10 year recurrence (dashed line). Each curve represents an average of 876 long-term stations. a), b)
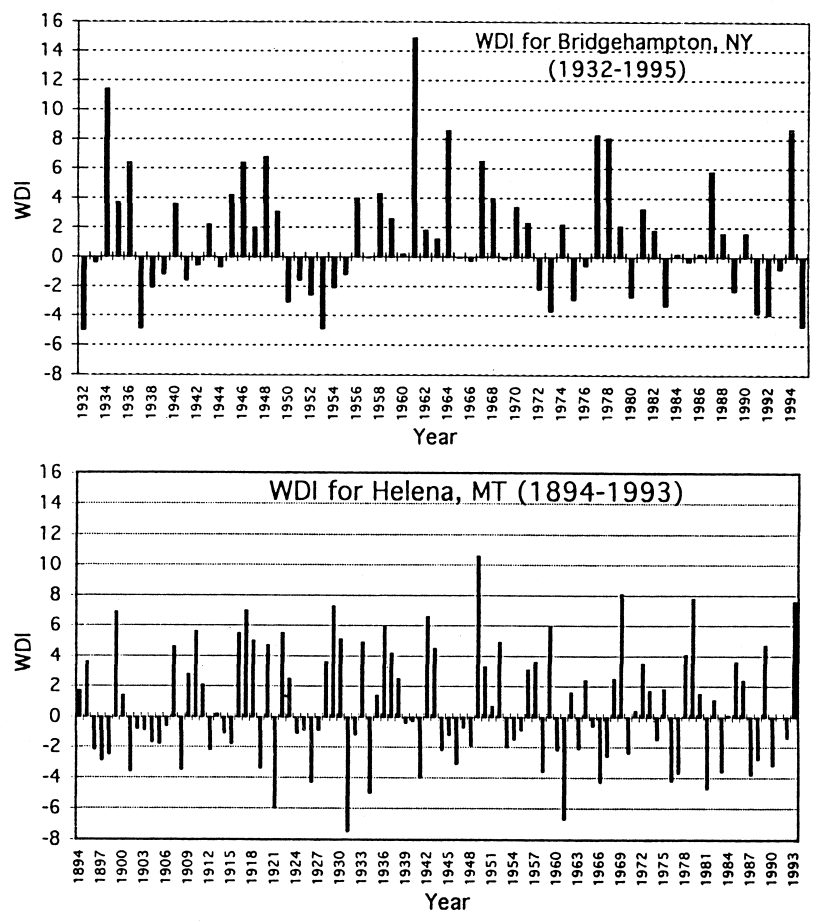

c)
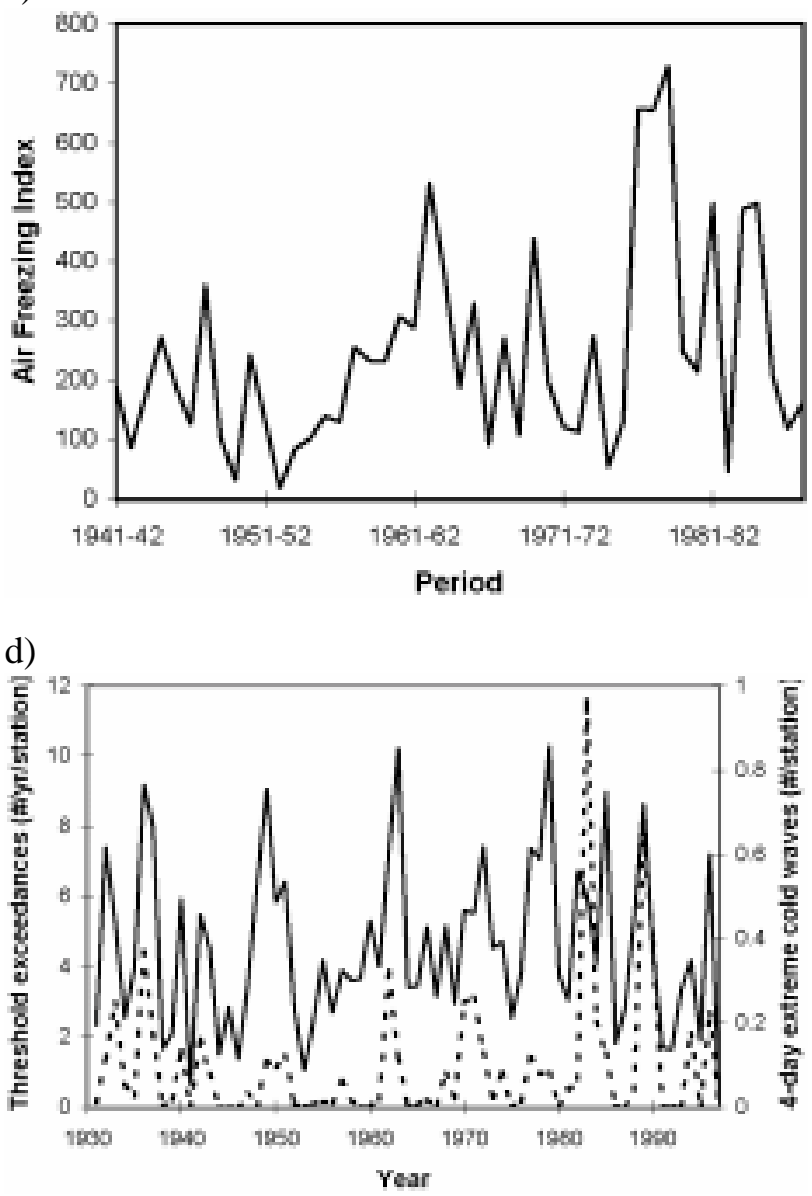
of +10 are extremely damaging and disruptive. The long-term distribution for Helena, Montana (Fig. 12a), shows positive (severe) conditions rather evenly distributed over the 100-yr period. The New York site (Fig. 12b) shows a rather disruptive period from 1956 to 1972 , but otherwise no long-term trend is present.

The depth to which soils freeze and thaw is important in the design of pavements, structures, and utilities in areas of seasonal frost. The penetration of freezing or thawing temperatures into soils depends on the size and duration of the temperature differential at the air-ground interface. An air freezing index has been developed to measure the extremes of those temperature periods that are particularly damaging to highways. Figure $12 \mathrm{c}$ presents the winter freezing indices for the St. Louis area from the 1940-41 winter through the 1987-88 winter (Snelling and Myles 1991). This shows considerable year-to-year variability, and clearly demonstrates the effect of three record cold winters in the late 1970s (Changnon et al. 1980). There is no statistically significant trend over this 47-yr period.

An analysis of cold waves was performed using the same method as that for excessive heat. The annual number of days with temperatures falling below a $1.5 \%$ probability threshold (Fig. 12d) exhibits peaks in 1963 and the late 1970s. The frequency appears to be decreasing slightly since the cold winters of the late 1970s. The annual number of extreme 4-day cold waves (Fig. 12d) indicate that there were widespread extreme occurrences in 1983 and 1989, with significant occurrences in several other years in the 1980s; this high number of occurrences in the 1980s is consistent with the high number of freezes in the Florida citrus-growing areas. However, the frequency of extreme cold waves during the 1990s has been similar to the long-term mean. Thus, there does not appear to be a trend in the frequency of these extremes.

\section{Conclusions}

This review shows that most measures of the economic impacts of weather and climate extremes over the past several decades reveal increasing trends in losses reaching a peak in the 1990s. This includes property and crop losses due to floods, hurricanes, thunderstorms, and winter storms. However, trends in the frequency/severity of most related atmospheric phenomena do not exhibit comparable increases with time. In general, the results of the review strongly sug- gest that the increasing financial losses from weather extremes are primarily due to a variety of societal changes. These include population growth along the coasts and in large cities, an overall increased population, more wealth and expensive holdings subject to damage, and lifestyle and demographic changes exposing lives and property to greater risk. This hypothesis clearly requires further research. The record in recent decades shows decreases in the frequency of intense hurricanes, and few overall changes in thunderstorm, hail, and tornado frequencies, droughts, and temperature extremes. The record of hydrologic floods is mixed. Some studies show increases in precipitation, but one recent study shows no trend in the highest levels of streamflow for the nation as a whole. A definitive link between variation in precipitation and damaging floods remains to be made (cf. Pielke and Downton 1999, manuscript submitted to J. Climate).

Loss of life due to weather extremes exhibits mixed outcomes over time. Little change is found in deaths due to lightning and extremely cold temperatures. Loss of life related to tornadoes and hurricanes has decreased with time, whereas loss of life due to extreme heat may have increased. The analysis supports the hypotheses that the downward shifts and the flat trends of lives lost (in the context of a growing population) are a result of improved warnings and other responses, whereas the possible increase in heat deaths is a function of societal conditions in larger cities. Another major finding is that trends in impacts and associated weather conditions exhibit large differences regionally across the United States. For example, crop-hail losses and hail-day frequencies have been increasing with time in the high plains but decreasing in the Midwest. Winter storms and their damages along the east coast have been increasing in recent decades, while they have been decreasing in the Great Lakes basin.

The results presented for the United States are in agreement with the findings of the 1995 Intergovernmental Panel on Climate Change (IPCC) report. At the regional level, studies have documented various increasing and decreasing trends in the frequency or magnitude of extreme events. On a global scale it is difficult for scientists to discern trends in extreme events. As the IPCC (1996, p. 173) notes, "Overall, there is no evidence that extreme weather events, or climate variability, has increased, in a global sense, through the twentieth century, although data and analyses are poor and not comprehensive. On regional scales there is clear evidence of changes in some 
TABLE 2. Selected recent sources of information on impacts and weather climate trends.

\begin{tabular}{|c|c|c|}
\hline Extreme & Impact sources & Weather-climate trend sources \\
\hline Floods & $\begin{array}{l}\text { National Weather Service } \\
\text { Pielke and Downton }(1999, \text { manu- } \\
\text { script submitted to J. Climate) }\end{array}$ & $\begin{array}{l}\text { Karl and Knight (1998), Karl et al. (1995a,b), Changnon and } \\
\text { Kunkel (1995), Kunkel et al. (1997), Lettmaier et al. (1994), } \\
\text { Lins and Michaels (1994), Lins and Slack (1999), Knapp (1994) }\end{array}$ \\
\hline Hurricanes & $\begin{array}{l}\text { Hebert et al. (1996), } \\
\text { Pielke and Landsea (1998) }\end{array}$ & Landsea et al. (1999) \\
\hline $\begin{array}{l}\text { Thunderstorms } \\
\text { (overall) }\end{array}$ & Changnon et al. (1996b) & Gabriel and Changnon (1989), Changnon (1997b) \\
\hline Hail & Changnon (1996) & Changnon (1995), Changnon et al. (1996) \\
\hline Tornadoes & Grazulis $(1993 b, 1997)$ & Grazulis (1993b, 1997) \\
\hline Winter storms & $\begin{array}{l}\text { Changnon et al. (1996b), } \\
\text { Angel (1998) }\end{array}$ & Davis et al. (1993), Angel (1998) \\
\hline Drought & Changnon et al. (1994) & Edwards et al. (1997), Riebsame et al. (1990) \\
\hline Extreme heat & $\begin{array}{l}\text { Changnon et al. (1996a), } \\
\text { Parish (1997) }\end{array}$ & Kunkel et al. (1996), DeGaetano (1996), Balling and Idso (1990) \\
\hline Extreme cold & Parish (1997), Miller (1988) & $\begin{array}{l}\text { Rogers and Rohli (1991), Nese and Knight (1997), Snelling } \\
\text { and Myles (1991) }\end{array}$ \\
\hline
\end{tabular}

extremes and climate variability indicators. Some of these changes have been toward greater variability; some have been toward lower variability." Our review of recent literature on trends in societal impacts and covarying physical measures is summarized in Table 2.

For specific types of impacts and extremes, we hypothesize the following.

1) Flood damages and fatalities have been higher over the last 25 years than the previous 65 years. The last 25 years have also been characterized by a high frequency of heavy rain events. Thus, there is reason to hypothesize that the observed impact trends are at least partially the result of climate trends. However, there has been no systematic study of changes in societal exposure and thus it is not possible to quantify the relative contribution of climate. More research is needed to better link precipitation trends with damaging floods.

2) There has been a steady and substantial increase in hurricane losses. However, there has been no corresponding upward trend in hurricane frequency and intensity. The observed increases are due entirely to increased societal exposure along vulnerable coastlines. The hurricane loss data, when normalized for exposure, do not show an increase over time.

3) The convective storm conditions (thunder, hail, tornado, and related insurance catastrophes) reveal three major findings. First, the temporal frequency of thunderstorms, hailstorms, and strong tornadoes do not show major national trends upward or downward. Second, regional storm conditions and their impacts do show varying trends, some upward and some downard with time. For example, since the 1960s, thunderstorm and hailstorm frequencies have been increasing in the high plains but decreasing in the Midwest. Third, losses from all storm conditions have been steadily increasing with time, suggesting that societal changes play an important role. Such changes include the growth in population, regional shifts in demographics, enhanced values of property, and other societal factors that make the United States more vulnerable to weather extremes. 
4) Winter storm damage has increased over the last 10 to 15 years in the East and decreased on the Great Lakes. There is evidence that increased frequency of intense nor'easters may be partially to blame for eastern U.S. losses. However, such factors as sea level rise and coastal development have increased societal vulnerability to such storms and at least some of the increase in losses is likely related to societal changes.

5) While the drought of 1988 stands out for its large losses, there is no evidence for a long-term trend in drought-related losses in the United States, although the data record is not complete. There is also no evidence for a trend in climatological drought frequency. The droughts during the 1930s and 1950 s remain the dominant events of this century.

6) Recent heat waves have caused extensive loss of life. Comparison with severe heat waves of the 1930s suggests that society is at increased risk for a variety of reasons, such as an aging population and cultural changes, accounting for recent increases. Further, there is no evidence that the frequency of severe heat waves has increased. The high frequency of intense heat during the 1930s dominates a time series of heat waves. During the last 15 years, there have been several intense cold waves. However, on a national scale, there is no compelling evidence for any trend, and cold-related deaths show no increase with time.

Acknowledgments. This study was supported in part by the Electric Power Research Institute and the National Science Foundation.

\section{References}

Adams, C. R., 1997: Impacts of temperature extremes. Workshop of the Social and Economic Impacts of Weather, R. A. Pielke Jr., Ed., National Center for Atmospheric Research, 11-15.

Angel, J. R., 1995: Large-scale storm damage on the U.S. shores of the Great Lakes. J. Great Lakes Res., 21, 187-293.

— Lake cyclones. J. Climate, 11, 61-71.

Avery, W. M., 1985: Heat and Your Heart: Heat Stress. Center for Environment Physiology, 12 pp.

Balling, R. C., and S. E. Idso, 1990: Effects of greenhouse warming on maximum summer temperatures. Agric. For. Meteor., 53, 143-147.

Changnon, S. A., 1977: The scales of hail. J. Appl. Meteor., 16, 626-648.

— 1982: User beware: The upward trend in tornado frequencies. Weatherwise, 35, 64-69.
_ 1995 : Temporal fluctuations of hail in Illinois. Miscellaneous Publication 167, Illinois State Water Survey, 19 pp.

_ 1996: Hail in Texas. National Crop Insurance Services, 22 pp.

, 1997: Trends in hail in the United States. Workshop of the

Social and Economic Impacts of Weather, R. A. Pielke Jr., Ed., National Center for Atmospheric Research, 19-33.

— , and K. E. Kunkel, 1995: Climate-related fluctuations in Midwestern floods during 1921-1985. J. Water Res. Planning Manage., 111, 326-334.

— phe data for use in climate change investigations. Climatic Change, 38, 435-445.

,-- , and P. Stone, 1980: Illinois third consecutive severe winter: 1978-1979. Illinois State Water Survey Report of Investigation 94, $31 \mathrm{pp}$. [Available from Illinois State Water Survey Library, 208 Water Survey Research Center, 2204 Griffith Dr., Champaign, IL 61820.]

—, M. H. Glantz, N. Fulton, M. Harper, G. Hewings, M. Mason, K. Muller, and A. D. Tarlock, 1994: The Lake Michigan diversion at Chicago and urban droughts. CRR 36, Changnon Climatologists, $221 \mathrm{pp}$.

— , K. E. Kunkel, and B. C. Reinke, 1996a: Impacts and responses to the 1995 heat wave: A call to action. Bull. Amer. Meteor. Soc., 77, 1497-1506.

—, D. Changnon, E. R. Fosse, D. Hoganson, R. J. Roth, and J. Totsch, 1996b: Impacts and responses of the weather insurance industry to recent weather extremes. CRR-41, Changnon Climatologists, $165 \mathrm{pp}$.

,,,,----- , and,- 1997 : Effects of recent weather extremes on the insurance industry: Major implications for the atmospheric sciences. Bull. Amer. Meteor. Soc., 78, 425-435.

Court, A., and J. F. Griffiths, 1986: Thunderstorm climatology. Thunderstorm Morphology and Dynamics, E. Kessler, Ed., University of Oklahoma Press, 9-40.

Crop-Hail Insurance Actuarial Association, 1978: Crop-hail insurance statistics. Crop-Hail Insurance Actuarial Association, Chicago, IL, 50 pp.

Davis, R. E., R. Dolan, and G. Demme, 1993: Synoptic climatology of Atlantic coast northeasters. Int. J. Climatol., 13, 171-189.

DeGaetano, A., 1996: Recent trends in maximum and minimum temperature threshold exceedences in the northeastern United States. J. Climate, 9, 1646-1660.

Donoghue, E. R., M. A. Graham, J. M. Jentzen, B. D. Lifschultz, J. L. Luke, and H. G. Mirchandani, 1997: Criteria for the diagnosis of heat-related deaths: National association of medical examiners. Amer. J. Forensic Med. Pathol., 18, 11-14.

Edwards, D. C., T. B. McKee, N. J. Doesken, and J. Kliest, 1997: A description of changes in drought events in the United States during the 20th century. Preprints, 10th Conf. on Applied Climatology, Reno, NV, Amer. Meteor. Soc., 188-189.

Ellis, F. P., 1972: Mortality from heat illness and heat aggravated illness in the U.S. Environ. Res., 5, 1-58.

FIFMTF, 1992. Floodplain Management in the United States: An Assessment Report. Volume 2, L. R. Johnston Associates, 862 pp. [Available from Federal Emergency Management Agency, Washington, D.C.]

Gabriel, K. R., and S. A. Changnon, 1989: Temporal features in thunder days in the United States. Climate Change, 15, 455477. 
Golden, J., 1997: Tornadoes. Workshop of the Social and Economic Impacts of Weather, R. A. Pielke Jr., Ed., National Center for Atmospheric Research, 43-47.

Grazulis, T. P., 1993a: A 110-year perspective of significant tornadoes. The Tornado: Its Structure, Dynamics, Prediction, and Hazards, Geophys. Monogr., No. 79, Amer. Geophys. Union, 459-466.

—_ 1993b: Significant Tornadoes 1680-1991. Environmental Films, 1326 pp.

_ 1997 : Significant Tornadoes: Update 1992-1995. Environmental Films, 1327-1444.

— C. A. Doswell III, H. E. Brooks, and M. Biddle, 1998: A new perspective of the societal impacts of North American tornadoes covering two centuries. Preprints, 19th Conf. on Severe Local Storms, Minneapolis, MN, Amer. Meteor. Soc., 196-199.

Hebert, P. J., J. D. Jarrell, and M. Mayfield, 1996: The deadliest, costliest, and most intense United States hurricanes of this century (and other frequently requested hurricane facts). NOAA Tech. Memo. NWS NHC-31, National Hurricane Center, $30 \mathrm{pp}$. [Available from National Technical Information Service, U.S. Department of Commerce, Springfield, VA 22161.]

IPCC, 1996: Climate Change 1995: The Science of Climate Change. Cambridge University Press, 572 pp.

Kalkstein, L. S., 1995: The impact of climate on human mortality: Present realities and future implications. Preprints, Ninth Conf. on Applied Climatology, Dallas, TX, Amer. Meteor. Soc., 217-227.

_ , and R. E. Davis, 1989: Weather and human mortality: An evaluation of demographic and inter-regional responses in the U.S. Ann. Amer. Assoc. Amer. Geogr., 79, 4-64.

Karl, T. R., and R. W. Knight, 1998: Secular trends of precipitation amount, frequency, and intensity in the United States. Bull. Amer. Meteor. Soc., 79, 231-242.

,-- _ climate variability in the twentieth century. Nature, 377, 217 220.

$\longrightarrow,-$ D. R. Easterling, and R. G. Quayle, 1995b: Trends in U.S. climate during the twentieth century. Consequences, 1, 3-12.

$-, \ldots, \ldots$, and $\_, 1996$ : Indices of climate change for the United States. Bull. Amer. Meteor. Soc., 77, 279-292.

Kilbourne, E. M., 1997a: Heat waves and hot environments. The Public Health Consequences of Disasters, E. K. Noji, Ed., Oxford University Press, 245-286.

_ $1997 \mathrm{~b}$ : Cold waves and cold environments. The Public Health Consequences of Disasters, E. K. Noji, Ed., Oxford University Press, 287-311.

Kithil, R., 1997: An overview of lightning safety. Workshop of the Social and Economic Impacts of Weather, R. A. Pielke Jr., Ed., National Center for Atmospheric Research, 53-54.

Knapp, H. V., 1994: Hydrologic trends in the upper Mississippi River basin. Water Int., 19, 199-206.

Kocin, P. J., 1997: Some thoughts on the societal and economic impact of winter storms. Workshop of the Social and Economic Impacts of Weather, R. A. Pielke Jr., Ed., National Center for Atmospheric Research, 55-60.

— eastern Coast of the United States: 1955 to 1985. Meteor. Monogr., No. 44, Amer. Meteor. Soc., 280 pp.
—, P. N. Schumacher, R. F. Morales Jr., and L. W. Uccellini, 1995: Overview of the 12-14 March 1993 superstorm. Bull. Amer. Meteor. Soc., 76, 165-182.

—, L. W. Uccellini, K. F. Brill, and M. Zika, 1998: Northeast snowstorms: An update. Preprints, 16th Conference on Weather Analysis and Forecasting, Phoenix, AZ, Amer. Meteor. Soc., 421-423.

Kunkel, K. E., S. A. Changnon, B. C. Reinke, and R. W. Arritt, 1996: The July 1995 heat wave in the Midwest: A climatic perspective and critical weather factors. Bull. Amer. Meteor. Soc., 77, 1507-1518.

— K. A. Andsager, and D. R. Easterling, 1997: Trends in the frequency of heavy precipitation events over the U.S. Preprints, 10th Conf. on Applied Climatology, Reno, NV, Amer. Meteor. Soc., 267-270.

Landsea, C. W., N. Nicholls, W. M. Gray, and L. A. Avila, 1996: Downward trends in the frequency of intense Atlantic hurricanes during the past five decades. Geophys. Res. Lett., 23, 1697-1700.

— , R. A. Pielke Jr., A. Mestas-Nuez, and J. Knaff, 1999: Atlantic Basin hurricanes: Indices of climate changes. Climatic Change, in press.

Lettenmaier, D. P., E. F. Wood, and J. R. Wallis, 1994: Hydroclimatological trends in the continental United States. J. Climate, 7, 586-607.

Lins, H. F., and P. J. Michaels, 1994: Increasing U.S. streamflow linked to greenhouse forcing. Eos, Trans. Amer. Geophys. Union, 75, $281 \mathrm{pp}$.

__, and J. R. Slack, 1999: Streamflow trends in the United States. Geophys. Res. Lett., 26, 227-230.

Meyers, M. F., 1997: Trends in floods. Workshop of the Social and Economic Impacts of Weather, R. A. Pielke Jr., Ed., National Center for Atmospheric Research, 77-86.

Storms, R. Pielke Jr. and R. Pielke Sr., Eds., Routledge Press, in press.

Miller, K. A., 1988: Public and private sector responses to Florida citrus freezes. Societal Responses to Regional Climatic Change: Forecasting by Analogy, M. H. Glantz, Ed., Westview Press, 375-405.

Nese, V. M., and P. G. Knight, 1997: A generalized winter disruptiveness index. Preprints, 10th Conf. on Applied Climatology, Reno, NV, Amer. Meteor. Soc., 223-227.

Ostby, F. P., 1993: The changing nature of tornado climatology. Preprints, 17th Conf. on Severe Local Storms: Conf. on Atmospheric Electricity, St. Louis, MO, Amer. Meteor. Soc., 15.

Parish, G., 1997: Impacts of weather on health. Workshop of the Social and Economic Impacts of Weather, R. A. Pielke Jr., Ed., National Center for Atmospheric Research, 87-90.

Pielke, R. A., Jr., 1996: Midwest Flood of 1993: Weather, Climate and Societal Impacts. National Center for Atmospheric Research, $159 \mathrm{pp}$.

_ Ed., 1997a: Workshop on the Social and Economic Impacts of Weather. National Center for Atmospheric Research, $136 \mathrm{pp}$.

_ $1997 \mathrm{~b}$ : Trends in hurricane impacts in the United States. Workshop of the Social and Economic Impacts of Weather, R. A. Pielke Jr., Ed., National Center for Atmospheric Research, 91-101. 
1999: Nine fallacies of floods. Climatic Change, in press. , and R. A. Pielke Sr., 1997: Hurricanes: Their Nature and Impacts on Society. John Wiley, $279 \mathrm{pp}$.

—_, and C. W. Landsea, 1998: Normalized hurricane damages in the United States: 1925-95. Wea. Forecasting, 13, 621-631.

Riebsame, W. E., S. A. Changnon, and T. R. Karl, 1990: Drought and Natural Resources Management in the United States: Impacts and Implications of the 1987-89 Drought. Westview Press, $191 \mathrm{pp}$.

Rogers, J. C., and R. V. Rohli, 1991: Florida citrus freezes and polar anticyclones in the Great Plains. J. Climate, 4, 11031113.

Roth, R. J., Sr., 1996: The property casualty insurance industry and the weather of 1991-1994. Impacts and Responses of the Weather Insurance Industry to Recent Weather Extremes, S. A. Changnon, D. Changnon, E. Ray Fosse, D. C. Hoganson, R. J. Roth Sr., and J. Totsch, Eds., CRR-41, Changnon Climatologists, 101-132.

Schaefer, J. T., R. L. Livingston, F. P. Ostby, and P. W. Leftwich, 1993: The stability of climatological data. The Tornado: Its Structure, Dynamics, Prediction, and Hazards, Geophys. Monogr., No. 79, Amer. Geophys. Union, 459-466.
Snelling, H. J., and G. Myles, 1991: Freezing indices-Yesterday, today, and tomorrow. Preprints, Seventh Conf. on Applied Climatology, Salt Lake City, UT, Amer. Meteor. Soc., 127-130.

Thompson, L. M., 1969: Weather and technology in the production of crops in the U.S. J. Soil Water Conser., 24, 219-230.

U.S. Congress, Bipartisan Task Force on Funding Disaster Relief, 1995: Federal Disaster Assistance, U.S. Senate, 104-4, 194 pp.

U.S. Senate Special Committee on Aging, 1983: Heat Stress and Older Americans: Problems and Solutions. U.S. Government Printing Office, 14 pp.

Yen, C.-L., and B.-C. Yen, 1996: A study on the effectiveness of flood mitigation measures. Proceedings of the 1st International Conference on New/Emerging Concepts for Rivers, International Water Resources Association, Ed., Rivertech 96, Vol. 2, International Water Resources Association, 555-562.

Zevin, S. F., 1994: Steps toward an integrated approach to hydrometeorological forecasting services. Bull. Amer. Meteor. Soc., 75, 1267-1276.

Zhang, K., B. C. Douglas, and S. P. Leatherman, 1997: East coast storm surges provide unique climatic record. Eos, Trans. Amer. Geophys. Union, 78, 389-397. 